\title{
14. Türkiye Türkçesinde fiilden isim yapan eklerin morfo-semantik işlevleri
}

\section{Çiçek VAROL ${ }^{1}$}

\section{Ahmet AKÇATAŞ²}

APA: Varol, Ç.; Akçataş, A. (2021). Türkiye Türkçesinde fiilden isim yapan eklerin morfo-semantik işlevleri. RumeliDE Dil ve Edebiyat Araştırmaları Dergisi, (23), 199-226. DOI: 10.29000/rumelide.948328.

\section{Öz}

İsim, canlı ve cansız bütün varlıkları karşılayan ve onları ifade etmemizi sağlayan kelimelerdir. İsimler, kök halinde olabileceği gibi birtakım sonek şeklindeki yapım ekleriyle türetilmiş de olabilir. İsim türeten yapım ekleri, isimden isim ve fiilden isim olmak üzere iki grupta ele alınır. Fiilden isim türeten ekler, fiil kök ve gövdelerinden isim yapmak için kullanılan eklerdir. Türkçe sondan eklemeli bir dil olduğu için, en yaygın sözcük oluşturma yöntemi biçimbilgisi ile de doğrudan ilgili olan türetimdir. Türetim, isim ya da fiil tabanlı kök veya gövdelere biçimbirimler eklenerek yeni bir anlama sahip sözcükler oluşturmaktır. Bu çalışmada morfo-semantik türetim ele alındı. Bazı ekler, eklendikleri kök veya gövdenin anlamıyla ilişkili anlam verirken bazıları da eklendikleri kelimelere yeni bir anlam vermektedir. Bu anlam ilişkisi de morfo-semantik adı altında incelenmektedir. Morfo-semantik, anlambilimin bir alt kolu olarak değerlendirilmekte ve eklerin, eklendikleri kelimelere kazandırdığı anlamları belirler. Morfo-semantik, eklendikleri sözcüklerle anlam ilişkisi kurmasını, eklendikleri kelimelerin anlamında, türünde ve yapısında değişiklik yapmasını inceler. Biçimbilimsel yeni yorumlar ve anlam değişmeleri ile dile yeni sözcük yaratma olanağı sağlar. Bu çalışmada incelenen eserlerde fiilden isim türeten eklerin morfo-semantik işlevleri üzerine duruldu. Genel gramer üzerine yapılan çalışmalardan fiilden isim türeten ekler belirlenerek, incelenen eserlerde bu eklerin morfo-semantik işlevleri tespit edildi. İncelenen eserler ve çalışmada yararlanılan kaynaklar, kaynakça kısmında belirtildi.

Anahtar kelimeler: İsim, fiil, morfo-semantik, türetim, anlam

\section{In Turkish the morpho-semantic functions of suffixes deriving nouns from verbs}

\begin{abstract}
Nouns are words that meet all living and non-living beings and enable us to express them. Nouns can be rooted or derived with some suffix-like construction suffixes. Noun-derived construction suffixes are handled in two groups, namely nouns from nouns and nouns from verbs. The affixes that derive nouns from the verb are the affixes used to make nouns from the verb root and stem. Because Turkish is an agglutinative language, the most common word formation method is derivation, which is directly related to morphology. Derivation is to create words with a new meaning by adding morphemes to the noun or verb-based stem or stems. In this study, morphosemantic derivation is discussed. Some affixes give meaning to the meaning of the root or stem to

Dr. Öğrencisi; Uşak Üniversitesi, Lisansüstü Eğitim Enstitüsü, Türk Dili ve Edebiyatı ABD (Uşak, Türkiye), vrl.cck.02@gmail.com, ORCID ID: 00o0-0002-8513-0941 [Araştırma makalesi, Makale kayıt tarihi: 17.02.2021-kabul tarihi: 20.06.2021; DOI: 10.29000/rumelide.948328]

Prof. Dr. Uşak Üniversitesi, Fen Edebiyat Fakültesi, Türk Dili ve Edebiyatı Bölümü (Uşak, Türkiye), ahmet.akcatas@usak.edu.tr, ORCID ID: 0ooo-0002-6611-0259

Adres | Address

RumeliDE Dil ve Edebiyat Araşttrmaları Dergisi $\quad$ RumeliDE Journal of Language and Literature Studies Osmanağa Mahallesi, Mürver Çiçeği Sokak, No:14/8 $\quad$ Osmanağa Mahallesi, Mürver Çiçeği Sokak, No:14/8

Kadıköy - İSTANBUL / TÜRKIYE 34714 Kadıköy - ISTANBUL / TURKEY 34714 e-posta: editor@rumelide.com

e-mail: editor@rumelide.com

tel: +90 505 7958124, +90 2167730616 phone: +90 505 7958124, +90 2167730616
\end{abstract}


which they are added, while others give a new meaning to the words they are added. This meaning relation is also examined under the name of morpho-semantic. Morpho-semantics is considered as a sub-branch of semantics and determines the meanings that affixes give to the words they are added. Morpho-semantic examines the relationship of meaning with the words they are added, making changes in the meaning, type and structure of the words they are added. Morphological new interpretations and with meaning changes provide the opportunity to create new words in the language. In this study in the works examined, the morpho-semantic functions of suffixes deriving nouns from verbs were focused on. The morpho-semantic functions of these suffixes were determined in the studied works by determining the affixes derived from the verb noun from general studies on grammar. The examined works and the sources used in the study are specified in the bibliography section.

Keywords: Noun, verb, morpho-semantic, derivation, meaning

\section{Giriş}

Türkiye Türkçesindeki sözcük türlerinden biri de isimdir. İsim, canlı ve cansız bütün varlıkları karşlayan onları ifade etmemizi sağlayan kelimelerdir.

Turgay Sebzecioğlu (2017, s.132), isim tanımını, "varlıklara, somut nesnelere ve soyut olgulara gönderimde bulunan, tümcede genellikle özne ve nesne konumlarında yer alan; kip, dilbilgisel zaman ve görünüş gibi kategorileri üzerinde taşımama veya bu tür kategorileri üzerine almama eğilimi gösteren temel sözcük türlerinden" olarak yapmaktadır.

Tahsin Banguoğlu(2011, s.319) isim konusunda, "gerçekte veya tasavvurda bir varlı̆̆a ad olan; bunlardan birtakımı duyularımızla kavranır bir gerçekliği olan varlıkların nesnelerin adı olan, birtakımı ise maddi varlıklara, nesnelere değil, vasıflara manevi kavramlara ad olan kelimeler" olarak tanım yapmaktadır.

Türkiye Türkçesinde isimler kök halinde olabileceği gibi birtakım son ekler ile türemiş isim de olabilirler. Soneklerin bir kısmı yapım ekleri grubunda yer almaktadır.

İsim türeten yapım ekleri, isimden isim ve fiilden isim türeten yapım ekleri olarak iki grupta incelenir. Çalışmamız itibariyle fiilden isim türeten ekler ele alındı. "Fiilden isim ekleri fiil kök ve gövdelerinden isim yapmak için kullanılan eklerdir. Bu ekler fiil köklerine, isimden yapılmış fiil gövdelerine ve fiilden yapılmış fiil gövdelerine eklenirler.” (Ergin, 2004, s.184-185).

Türetme ile oluşturulan kelimeler morfolojinin alanına girmektedir. Morfoloji veya biçim bilgisi, "Bir dildeki kök ve ekleri, bunların birleşme yollarını, eklerin anlam ve görevlerini, dilin türetme ve çekim özelliklerini ve şekille ilgili öteki konuları inceleyen dilbilgisi dalı (Vural ve Böler, 2012, s.139)” olarak tanımlanmaktadır.

"Türkçe sondan eklemeli bir dil olduğu için, yeni bir kavramı karşılamak üzere biçimbilgisi ile doğrudan ilgili olan türetim, en yaygın sözcük oluşturma yöntemidir. Türetim ad ya da eylem tabanlarına biçimbirimler getirmek suretiyle söz konusu ad veya eylem tabanından yeni bir anlama sahip sözlükbirimler oluşturmaktadır” (Karaoğlu, 2018, s.185). Eklerin, eklendikleri kelimelere kazandırdığı anlam ise morfolojinin alt kolu olan morfo-semantik olarak tanımlanabilir.

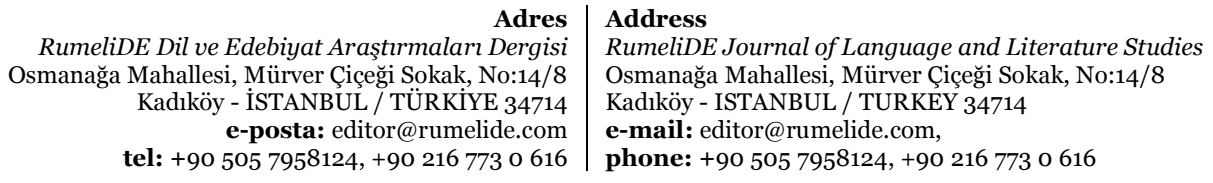

tel: +90 505 7958124, +90 2167730616 
Morfo-semantik türetim ile kimi ekler, kök anlamı ile bağlantılı olmalarına rağmen, kimi ekler de kök anlamından farklı bir anlam vermektedir. Kimisi de tek başına anlamı olmayan kelimelerden yeni bir sözcük oluşturmuşlardır. Bunlardan biri de çalışmamıza konu olan fiilden isim türeten eklerdir.

\section{Fiilden isim türeten eklerin morfo-semantik işlevleri}

İşlev ve anlam arasında bir ilişki vardır. Değer verdiğimiz bir şey aynı zamanda anlamlı olmaktadır. Ancak işlev, anlama göre daha sınırlı kavramdır. İşlev bir görevi yerine getirirken, anlam farklı farklı olabilir. Şöyle ki her sözcük bir kavram birimidir. Anlamlarını da dildeki kullanışları sınırlar, belirler. $\mathrm{Bu}$ gerçeği göz önünde bulundurmadan sözcükleri tek tek ele alıp anlam açısından yargılamak, yanıltıcı bir tutumdur. Ekler üzerinden açlklayacak olursak, bir ekin işlevi bellidir. Sadece o işlevi yerine getirmek için kullanılır. Tek başına kullanıldığı zaman işlev özelliği gösterebilir ancak bağlam içerisinden o işlevden farklı bir anlam kazanabilir. İşlev sınırlı, anlam geniştir. İşlev bellidir, anlam muğlaktır. İşlev, dilbilgisi kurallarını yerine getirirken, anlam için, anlambilim ön plandadır. İşlev, aynı zamanda anlam olabilir fakat anlam, işlev olamaz. Aşă̆ıda örnekler üzerinden eklerin işlevlerinden ziyade bağlam içerisinde kazandıkları anlam gösterilmeye çalışılmıştır. Ekler de sözcükler gibi, anlama etki eden, sözdizimini tamamlayan bir unsur olduğu görülmüştür. Aşağıdaki örnekler maddeler halinde sıralanarak anlam çeşitlilikleri gösterilmeye çalışılmıştır.

$-A$ :

Aslında zarf-fiil eki olan -A, tespit edilen örneklerde yapım eki olarak, eşli veya zıtlı tekrarlama yoluyla, -lAşs işteşlik fiilinden kurulmuş şekillerde kullanılmış ve fiilin kök anlamını değiştirmiştir.

1. "Çok zaman geçmez beni karşında süngü, kurşun yarasından yapılmış nişanlarla süslü görsün." (VYS, s. 21)

"Dikişe, oyaya başlad, hanım hanımcık yaşıyordu, memnundu." (TTF, s.58)

Yarmak fiili bir şeyi bölmek, ayırmak anlamında iken -A eki ile yarmak fiilinin oluşturduğu kesik anlamına getirilmiştir. -A eki, soyut bir hareketten somut bir anlam yüklemektedir. Aynı somut anlam oya kelimesinde de görülmektedir. Oymak, delmek, çukur oluşturmak anlamlarını ifade ederken -A eki ile birlikte genellikle ipek ibrişim kullanarak iğne, mekik, tı̆̆ veya firkete ile yapılan ince dantel anlamına ${ }^{3}$ gelmektedir.

2. "Uzun süre Fransa'da yaşamış, bu süre kendini ifade ettiği bütün dillere yansıyacak denli etkili olmuştu.” (BİS, s. 22)

Sürmek fiili zaman bakımından devam etmek anlamı taşırken, süre kelimesi zaman dilimi, geçen zaman aralığı anlamı taşımaktadır.

3. “...salıncă̆ı yatak diye nöbetleşe kullanarak gelmişler...” (AN, s. 10)

Nöbetleşmek fiili, sıra ile nöbet tutmak anlamına gelirken, -A eki eklenerek sıra sıra, dönüşümlü olarak anlamı kazanmaktadır.

3 Sözcük anlamları için Türk Dil Kurumu Güncel Türkçe Sözlük’ü kullanılmıştır.

Adres | Address

RumeliDE Dil ve Edebiyat Araştırmaları Dergisi $\quad$ RumeliDE Journal of Language and Literature Studies

Osmanağa Mahallesi, Mürver Çiçeği Sokak, No:14/8 Osmanağa Mahallesi, Mürver Çiçeği Sokak, No:14/8

Kadıköy - İSTANBUL / TÜRKIYE 34714 Kadıköy - ISTANBUL / TURKEY 34714

e-posta: editor@rumelide.com e-mail: editor@rumelide.com,

tel: +90 505 7958124, +90 2167730616 phone: +90 505 7958124, +902167730616 
4.“...toplumlar, içlerine kwvrla kwvrla, adeta, çehresi olmayan amorf bir kitleye dönüşmüşlerdi.” (FÖ, s. 21)

Kıvrılmak fiili, eğilip bükülmek anlamı taşırken, aldığı -A eki ve -lAş işteklik ekinin de eklenmesiyle bir ikileme özelliği kazanarak içe dönük, kendi kabuğuna çekilmek, dışa kapalı hale gelmek anlamına gelen kıvrıla kıvrıla ikilemesini oluşturmaktadır.

\section{-AcAk:}

Aslında sıfat-fiil eki olan ek, eklendiği sözcüklerle kalıcı isim oluşturmuştur. Bu yolla oluşmuş bulunan adlar, "bir şey için" anlamında tahsis adlarıdır.

\section{1. "Yiyecek, içecek sıkıntıları azalmıştı." (KY, s. 186)}

Yemek ve içmek fiilleri ağızda bir şeyler çiğnemek, bir sıvıyı ağız yoluyla yutmak anlamlarında iken -A eki getirilerek bu eylemin sonucu olarak yenilebilen ve içilebilen her şey, somut bir şey anlamını ifade etmektedirler.

\section{2. “Dinlenişini ve atılımını zamanlayamayan toplumlar için, gelecekler karanlıktır.” (FÖ, s. 10)}

Bu ek, sıfat-fiil eki olmasına rağmen bazı kökler ile kalıplaşarak kullanılmaktadır. Gelecek kelimesi de bunlardan biridir. Gelecek kelimesi, gerçekleşmesi beklenen, daha gelmemiş günler anlamını ifade etmektedir.

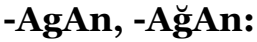

Bu ek, işlek olmamakla birlikte eklendiği fiillerde anlam değişikliği yapmaktadır. Fiilin ifade ettiği işi çokça yapan, onu adet haline getirmiş olan anlamında sıfatlar yapmaktadır.

\section{1. “... olağanüstü iri gözleri dokunduğu yeri asit dökülmüş gibi eriten...”(BİS, s. 36)}

-AğAn eki, fiilin ifade ettiği işi çokça yapma anlamı vermektedir. Olağan kelimesi tek başına kullanıldığında sık sık olan anlamı taşırken, birleşik kelime oluşturarak alışılmıştan farklı olan anlamı ifade etmektedir.

2. "Büyük atılımlardan sonra toplumlarm da adeta kişiler gibi bir dinleniş dönemine girmeleri olağan karşllanabilir.” (FÖ, s. 10)

Bu örnekte de olağan kelimesinin tek başına kullanıldığı görülmektedir. Olmak fiili, meydana gelmek anlamına gelmektedir. Aldığı ek ile birlikte, doğal karşılanan, alışılmış olan, normal bir durum olarak görülen anlamlarında olağan kelimesini türetmektedir.

3. “... ilişsilerini kurtarmak içgüdüsünden çok, bendeki süreğen 'izcilik ruhu’ndan kaynaklanıyordu bu.”(BİS, s. 44)

Süreğen kelimesi, ne kadar süreceği belli olmayan anlamının yanında uzun süre devam eden anlamı da taşımaktadır. -A ĂAn eki, burada, cümle içerisindeki anlamına bakıldığı zaman uzun zamandan beri devam bir zamanı ifade etmektedir.

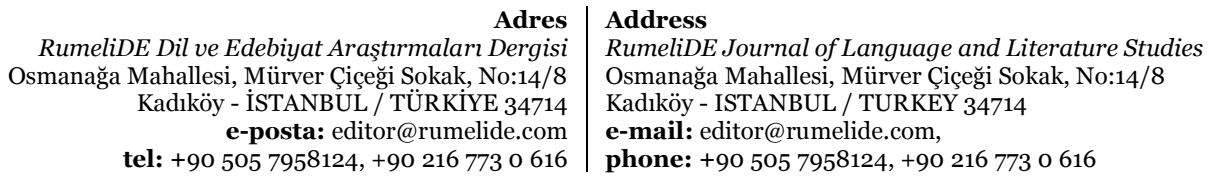




\section{-(A)k:}

Oldukça işlek bir ektir. Genellikle bir alışkanlığı, bir duyguyu ve bir fiilin bildirdiği işi çokça yapanı gösteren sıfatlar yapar. Araç-gereç isimleri ve somut ve soyut adlar türetir (Korkmaz, 2009, s.70; Ergin, 2004, s.188). Tespit edilen örneklerde -(A)k eki, fiillere soyut ve somut anlam, araç-gereç anlamı ve alışkanlık, ihtiyat anlamları yüklemektedir.

1.“... hele gençlerin isteklerine karşı büyüklerin uygun bularak seçtiği biriyle evlenmenin haksızh̆̆ı...”(SER, s. 73)

-(A)k eki, istemek fiiline gelerek bir duyguyu ifade eden talep anlamı vermektedir.

\section{2. “... büyük yuvarlak gözlerine aksettirdiği bir tür vahşilik...” (BİS, s. 5)}

Büyük ve yuvarlak kelimeleri, -(A)k eki alarak fiillerin bildirdiği işin sonucu, boyut ve şekil anlamlarını bildirmektedir. Benzerlerine göre boyutu fazla olan ve dairesel şekle sahip göz ifade edilmektedir.

\section{3. "En sonra, korkak ve suya sabuna dokunmayan zavall birtakım çocuklar gelir ki...” (KY, s. 21)}

Korkak kelimesine korkan kimse anlamında kullanılmıştır. -(A)k eki, bu örnekte fiilin bildirdiği işi huy edinme, kişisel bir özellik anlamları vermektedir.

\section{4. “... en işlek caddesine gidip bir kenara dikilmişti.” (BİS, s. 35)}

-(A)k eki bu örnekte fiillin bildirdiği işin sonucu olarak karşımıza çıkmaktadır. İşlemek fiili durağan durumdan hareketli duruma geçme anlamı taşırken, işlek sıfatı canlı, hareketli, cümle içerisinde herkesin geldiği bir caddeyi niteleyen anlamlarıyla fiilin tamamlanmış halini göstermektedir.

\section{5. “Uzaktan uzağa top sesleri işitilmeye başlar.” (VYS, s.57)}

Uzak kelimesi, -(A)k getirilerek boyu uzamak veya çok zaman geçmek anlamlarından rrak, çok ötelerde bulunan, ulaşması çok uzun süren bir yer anlamına geçmektedir.

\section{6. “... değgnĕ̆ini ayaklarının ucuna dayadı...”(KY, s.8)}

-(A)k eki, değmek fiilini, araç- gereç anlamı taşıyan bir isim haline getirmektedir. Değnek kelimesi, kullanılan eşya veya nesne olarak sopa anlamı taşımaktadır.

\section{7. “...karyolasına doğru yöneldi, yată̆ın örtüsünü açmadan...”(AN, s. 14)}

Yatmak fiili, uzanmak, uyumak anlamları taşırken, yatak kelimesi, üzerine yatılan veya üzerinde uyunan eşya anlamı taşımaktadır. -(A)k eki, fiilin gösterdiği hareketten o hareketin yapıldığı yer anlamına gelen kelime türetmektedir.

\section{-AmAk:}

Eylem kökünden isim yapan -A eki ile isme dönüştürücü -mAk ekinin birleşmesinden oluşmuştur (Karaca, 2013, s.270). Eklendiği fiillere bir işin aralıklarla yapıldığı veya o işin yapıldığı yer anlamı vermektedir.

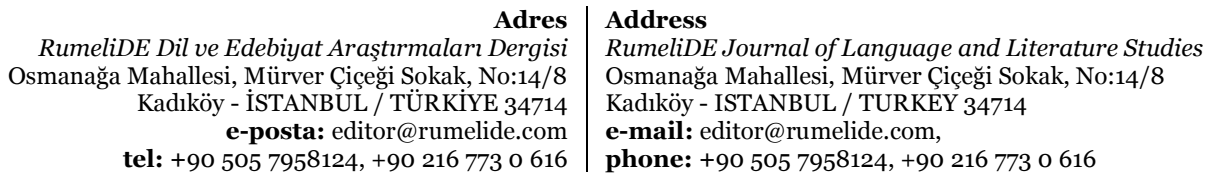


1. “Birinci, ikinci basamaklarn geçerek üçüncüsünde bacakları...”(SER, s.107)

-AmAk eki, bas fiiline birbirine ardına sıralan bir yüzey, bir yer kavramı anlamı vermektedir.

-An:

Aslında geniş zaman sıfat-fiil eki olan -An, kalıcı isimler yapmakla (Korkmaz, 2009, s. 73) birlikte eklendiği fiillere süreklilik ve o işi yapan, eden anlamı vermektedir.

1.“Şakaklarından tepesine doğru azalan saçları...”(BİS, s.12)

Azalmak fiili, az denecek miktar anlamına gelmektedir. Azalan kelimesi de aynı anlamı taşımakla beraber -An eki, karşılaştırma yapmadan şu anki durumu göstermiş ve azalan şeyin belirsizliğini ortadan kaldırmıştır.

2.“Bilginler, erenler, şairler, sanatçılar...” (FÖ, s. 27)

Ermek fiili, Allah yolunda masivadan uzaklaşma, olağanüstü sezgilere sahip olma anlamını bildirmektedir. -An eki alarak, Allah yolunda kendini adamış, ermiş, olağanüstü sezgilere, hislere sahip olan kimse anlamında eren kelimesini türetmektedir.

-AsI:

Eski Anadolu Türkçesinde çok işlek bir sıfat-fiil eki olan ek, Türkiye Türkçesinde kalıp halinde bazı ifadeler bırakarak kaybolmuştur (Korkmaz, 2009, s.75). Eklendiği fiillere yapılan işin sonucu, istek, dua ve beddua anlamı vermektedir.

1.“Nereye gitsen, kimi görsen, o kahrolası karşılaştırmayı yapıyorsun ister istemez.” (BİS, s.46)

-AsI ekinin beddua anlamına gelen bir kelime türetmektedir. Kahrolmak fiili, çok üzülmek anlamına gelmektedir ancak -AsI ekini alarak beddua olarak kullanılan, istenmeyen veya severek yapılmayan bir durum karşısında hiç olmasaydı veya bir diğer beddua terimi olarak kullanılan "lanet olsun" anlamında yeni bir anlam vücuda getirmektedir.

2. “Hem öyle erkek ki, kalbim şu erkek giysilerimle göründüğümden de erkek.” (VYS, s. 61)

-AsI eki bu örnekte de kıyafet anlamında kalıcı isim yaptığı görülmektedir.

3. “Uğruna ölünesi bir sevgilidir ki insana ölünce can bağışlar, şan bağışlar.” (AN, s.117)

Ölmek fiili, hayat belirtisi göstermemek, yok olmak, canlılığın sona ermesi anlamına gelmektedir. -AsI eki, bu fiilin gösterdiği işi, sevgi ifadesine dönüştürmektedir. Uğruna canını vermeye razı olan, ölecek kadar çok sevmek anlamında ölünesi kelimesi türetilmiştir.

-cA:

Fiillerden o fiilin ürünü, sonucu olan isimler yapar. Ekin bu işlevi çok işlek değildir (Karaca, 2013, s.59). eklendiği fiillere akılda tasarlanan bir şeyin harekete dökülmüş, sonuçlandırılmış ve soyutlaştırılmış anlamı vermektedir.

\begin{tabular}{|c|c|}
\hline Adres & \\
\hline RumeliDE Dil ve Edebiyat Araşttrmalar De & iDE Journal of Language and Literature Studies \\
\hline manağa Mahallesi, & ă̆a Mahallesi, Mürver Çiçeği Sokak, No:14/8 \\
\hline Kadıköy - İSTANBUL / TÜRKIYE 34 & - ISTANBUL / TURKEY 34714 \\
\hline $\begin{array}{l}\text { e-posta: editor@rumelide.com } \\
\text { tel: }+905057958124,+90216773 \text { o } 616\end{array}$ & $\begin{array}{l}\text { editor@rumelide.com, } \\
\text { +90 } 5057958124,+90216773 \text { o } 616\end{array}$ \\
\hline
\end{tabular}


1."Bunları duydukça ruhum bedenime slğmıyor, gönlümde güller açıyor, düşüncelerimde güneşler doğuyor.”(VYS, s.61)

-cA eki, düşünmek fiilinden zihinde oluşturulan imgeleri, tasarı veya niyet anlamına gelen düşünce kelimesini yapmıştır. Başlangıçta tasarlanan fikirlerin daha sonra amaç haline getirilmesi görülmektedir.

2. "Oysa bilim ve düşünce adamlarmı bu yönde uyarmah, örgütlemeli ve işi onlara brrakmalıydılar.”(FÖ, s. 111)

Bu örnekteki düşünce kelimesi, zihinde oluşturulan niyetten ziyade onu iş veya meslek haline getiren kimse anlamı taşımaktadır. Cümle içerisinde adam kelimesi ile birlikte, fikirlerine önem verilen kimse anlaminı ifade etmektedir.

3. "Bu cuma gezintileri de mahalledeki çocuklarm pek mühim ĕglencelerinden biri idi.” (KY, s. 23)

Eğlenmek bir fiil iken -cA eki ile birlikte fiilin ifade ettiği işe soyut anlam vermektedir.

\section{-cAsInA:}

Sıfat-fiil işlevindeki kip eklerinin üzerine gelerek zarfa dönüştürme işlevi görür. Kelimeyi zarfa dönüştüren aslında -CA ekidir. Kelimenin -CA ekli şekli kullanıma pek elverişli olmadığından -CA, sInA ekiyle kalıplaşarak -CasInA biçimini kazanmıştır (Karaca,2013, s.286). Bu tarz bildirme, benzetmeye ya da farazi karşılaştırmaya dayanan ve asıl fiile aynı zamanda gerçekleşen bir kılışa dayanır (Korkmaz, 2009, s. 76). Tespit ettiğimiz örneklerde de fiilin kök anlamında benzetme anlamı vermektedir.

1.“Okşarcasına dokundum, parmaklarımı gezdirdim yüzyılların üzerinde.” (BİS, s. 47)

-cAsInA eki, okşamak fiiline benzetme, gibilik anlamları vermektedir. Okşamak gibi, okşamak istercesine anlamını ifade etmektedir. Dokunma işinin nasıl ve ne şekilde yapıldığını göstermektedir.

2. "Sevgili adı anılınca kendinden geçmek, esrar içmişçesine donup kalmak." (AN, s. 123)

Bu örnekte de, gibi ve benzerlik anlamının yanında cümle içerisinde esrarın verdiği etkiyi tam anlamıyla yaşamış, tepki vermeme derecesine gelmek anlamı da ifade edilmektedir.

3. “...tamburun tellerine, genç kız kalbinin bütün duyarhlığını temas ettirircesine...”(AN, s. 2)

Temas etmek, dokunmak anlamını ifade etmektedir. Cümle içerisinde aldığı ek ile birlikte, kalple dokunmak, bütün hissiyatını vererek, duygularıyla dokunarak anlamını bildirmektedir.

4. “...bir zemberekten boşanmışçasına sökün eden değişimler...” (FÖ, s. 19)

Boşanmışçasına kelimesi, hızlı bir şekilde, süratle anlamını ifade etmektedir. Zembereğin hızlı ilerleyen yayları, hızla geçen zaman ifade edilmektedir.

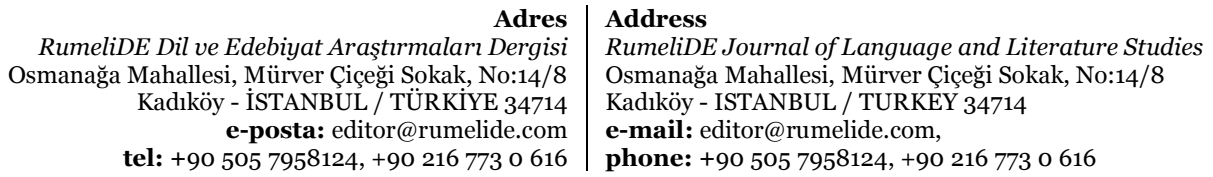

tel: +90 505 7958124, +90 2167730616

phone: +90 $5057958124,+90216773$ o 616 
-ç:

İşlek bir ektir. Dönüşlü fiil gövdelerine gelir. Fïldeki hareketi yapanı, yapılan hareketi veya o hareketle ilgili bir niteliği, bir özelliği gösteren soyut isim ve sıfatlar yapar (Vural ve Böler, 2012:172-173; Ergin, 2004:191). Anlam değiştirme özelliğinden çok yine fiilin kök anlamında fiillerden o fiilleri adlandırmaya dayalı ‘özellik’ anlatan kavramlar türetmektedir.

1.“Inancenda, Allah’, yarattıklarmı kendi adaletinin bilinciyle...”(VYS, s.50)

İnanmak fiili, bir şeyin varlığını, doğruluğunu kabul etmek anlamına gelirken; -ç eki de yine kökün ifade ettiği özelliği harekete dökme anlamı vermektedir. İnanç kelimesi, cümle içerisinde herhangi bir dine olan bağlılık ifadesi belirtilmiştir.

\section{2. “Birdenbire Esirci’nin o büyük, o korkunç gözlerini açarak...” (SER, s. 7)}

Korkunç kelimesi de -ç eki ile birlikte korkma işini yapan, ürkünçlüğü gösteren anlamı taşımaktadır. ç eki, fiildeki hareketi yapanı, yapılan hareketi veya o hareketle ilgili bir niteliği, bir özelliği gösteren isim yapmaktadır.

\section{-DIk, -DUk:}

Aslında sıfat-fiil ekidir. Fiillere gelerek geçmiş zaman işlevinde sıfatlar yapmaktadır. Yine kök anlamından uzaklaşmadan fiillere gelerek önceden, eskiden yapılan bir şey anlamı vermektedir.

“Tanıdık, sanki yanık bir ezgiydi bu." (BİS, s. 47)

“Günnar, o eski, bildik, uygar, yumuşak, dost bakışların giyiniverdi çabucak.” (BİS, s.53)

“Ama alışılmadık, yabancı.” (GK, s.95)

-DIk eki, tanımak, bilmek ve alışmak fiiline geçmiş zaman işlevinde, daha önceden veya eskiden yapılan eylemin içinde bulunulan zaman tekrarlanması anlamı vermektedir.

\section{-DIkçA/ -DUkçA:}

-DIk/ -DUk sıfat-fiil ekinin -çA zarf türetme ekiyle kaynaşmasından oluşmuş çok işlek bir zarf-fiil ekidir. Geçişli, geçişsiz, tek ve çok heceli bütün fiillere gelebilen ek, “-dığı sürece, -dığı zaman” anlamı veren ve bir işin art arda veya belirli aralıklarla tekrarlandığını gösteren bir görev yüklenmiştir (Korkmaz, 2009:78).

1. “... ama komşu evin sahibi siz olmadıkça, komşunuzu seçemezsiniz.” (BİS, s. 20)

“-dığı sürece, -dığı zaman” anlamı vermektedir. Olmadığı sürece, fiilin bildirdiği iş yerine gelmediği zaman anlamları bildirilmektedir.

2. “Anlattkça daha çok yoruluyor, yaşlanıordu sanki.” (BİS, s. 46)

Anlattıkça kelimesi, bir işin art arda veya belirli aralıklarla tekrarlandığı anlamını göstermektedir.

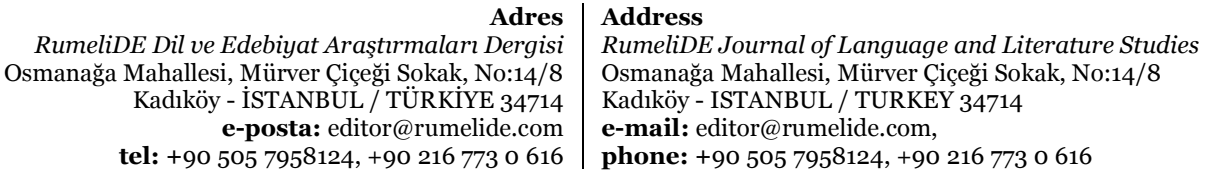


3. "Bulunduğumuz havaalanının dış hatlar binası oldukça küçüktü.” (BİS, s. 12)

Oldukça kelimesi, cümle içerisinde epey, olabildiğince, olabildiği kadar anlamları vermektedir.

4. "Doğulu bir güzelliğin yıllar geçtikçe katmerlenen esmer büyüsüne sahip zarif, nahif, asil bir hanımefendiydi..." (AN, s. 2)

Geçmek fiili, bir şeyi aşıp bitirmek anlamına gelirken, -DIkçA ekini alarak artarak, çoğaldıkça anlamları ifade etmektedir. Yılların birbiri ardı sıra bitip bir yeni yılın başlaması ve bu yılların birikerek çoğalması anlatılmaktadır.

5. “İslam Avrupa'ya yayıldıkça bunlar büsbütün kızgınlaşıp binbir set inşasına girecekler.” (FÖ, s. 20)

Yaymak fiili, etrafa dağılmak, genişlemek anlamına gelmektedir. Bu ek ile birlikte, “-dığı sürece” ve cümle içerisinde herkesin zamanla haberdar olduğu, geniş bir kitleye yayılan anlamında yayldıkça kelimesini türemektedir.

-gA:

Fiillerden, o fiilin anlamına ilişkin isimler yapar. Fiilden türemiş isim, türetildiği fiildeki hareketi yapanı veya harekete maruz kalanı ifade eder. Bunlar -genellikle- eşya, alet, unsur ifade eden isimlerdir(Karaca, 2013, s.114).

\section{1. “Eline bir süpürge vererek süpüreceği odaları...”(SER, s. 11)}

Süpürge kelimesi, süpürmek fiilini eyleme döken, eylemi yapmaya yardımcı bir alet ismi anlamı taşımaktadır.

-gAç:

Fiil kök ve gövdelerinden ad ve sıfat türeten bir ektir. Eklendiği fiil gövdeleri genellikle $-\mathrm{n}$ - ve $-\mathrm{r}$ - çatı eki almış gövdelerdir (Ergin, 2004, s.190). Fiillere huy bildiren ve kişilik özelliği anlamı vermektedir.

1.“... nedense biraz utangaç asılı kaldılar bir süre.” (BİS, s. 50)

-gAç eki, utanmak fiiline huy bildiren, kişilik özelliği anlamı vermektedir. Cümle içerisinde bir durum karşısında içsel yapılarının ortaya çıkardığı bir kişilik özelliği bildirilmektedir.

\section{-GAn:}

Fiilin bildirdiği işi, alışkanlık haline getirmiş olanı ifade eder (Vural ve Böler, 2012:173). Bu ek de fiile, huy ve alışkanlık, abartma anlamı vermektedir.

\section{1.“... bu zayıf mahluk gecenin unutkan kollarmda uyuyordu.” (SER, s. 26)}

Fiilin bildirdiği işi, alışkanlık haline getirmiş olan veya huy gösteren abartma anlamı vermektedir.

2. "Bunlarn hemen hemen hepsi mektebe gider ve çalışkander." (KY, s. 20)

\begin{tabular}{|c|c|}
\hline & \\
\hline eliDE Dil ve Edebiyat Araşttrmaları De & E Journal of Language and Literature Studies \\
\hline 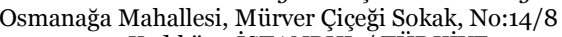 & Mahallesi, Mürver Çiçeği Sokak, No:14/8 \\
\hline Kadıköy $-\mathrm{I}$ & ISTANBUL / TURKEY 34714 \\
\hline $\begin{array}{r}\text { e-posta: editor } \\
\text { tel: }+905057958124,+9\end{array}$ & $\begin{array}{l}\text { editor@rumelide.com, } \\
\text { +90 505 7958124, +90 } 2167730616\end{array}$ \\
\hline
\end{tabular}


Çalışkan kelimesi, çalışma işini severek yapan, gayretli anlamlarına gelmektedir. -Gan eki, fiilin bildirdiği işi yapanı, işi çokça yapan anlamları vermektedir.

\section{-gIç, -gUç:}

Fiillerden, yapmaya maruz kalan nesne, yapan veya olanı anlatan isimler yapar. Eklendiği fiilin ürünü isimler yapar. Bu isimlerin bir kısmı sıfat olarak da kullanılır (Karaca, 2013, s.119). Fiillere kök anlamının bildirdiği ifadeden uzaklaşmamakla birlikte işi yapan veya işten etkilenen anlamı vermektedir.

\section{1.“Oradakilerden biri, bilgiç bir tavırla:" (KY, s. 92)}

-gIç eki, fiilin gösterdiği işi yapanı veya yapılan işten etkileneni göstermektedir. Bilmek fiili, -gIç eki alarak bilgili kimse anlamına gelmektedir. Cümle içerisinde ise, bilgisiz olmasına rağmen bilgili davranan anlamı verilmektedir.

2.“Hatta üçüncüsü, metafizik hayatımızın başlangıç noktası.” (FÖ, s. 45)

Başlamak fiili, bir işe girişmek veya oluşmaya başlamak anlamına gelmektedir. -gIç ekini alarak, cümle içerisinde hayatımızın ilk günü, var olmaya başladığımız an, sıfır noktası anlamını ifade etmektedir.

\section{-GI, -GU:}

Eklendiği fiilin son ses durumuna göre, ön sesi tonlu ve tonsuz biçimler alabilen ek, genellikle tek heceli fiil kökleriyle çeşitli çatı ekleri almış fiil gövdelerinden adlar türeten çok işlek bir ektir (Korkmaz, 2009, s.80-81). Fiillere somut ve soyut anlam yüklemekle birlikte araç-gereç anlamı da vermektedir.

1. “İçkinin zayıflattığı sinirleri, daha fazla tahammül edemeyecek gibi görünüyordu.” (KY, s. 57)

-GI eki, fiilin bildirdiği işten tüketilen bir içecek anlamında kelime yapmaktadır. İçki kelimesi, içinde alkol bulunan içecek anlamına gelmektedir.

2. “... su muhallebisi satan bir serginin arkasinda durdu.” (KY, s.32)

-GI eki burada, alıcının görmesi için dizilmiş şeyler anlamı vermektedir.

3. “Bu yüzden onun kafa tutuşu dudak kıvrımlarında, alaycı, inanmaz, galiba acıdiğı için gülmüyor çizgilerinde gizliydi.” (BİS, s. 22)

Çizgi, çizme işinin yapıldığı, çizme işinden sonra ortaya çıkan iz anlamı taşımaktadır. Cümle içerisinde, yüz hatlarında oluşan çizgi anlamındadır.

\section{4. “Aklında olsun, gönlümdeki sevginle vatan sevgisini yarıştırmaya kalkışma.” (VYS, s. 76)}

Sevmek fiili, birine veya bir şeye karşı duyulan bağllık anlamına gelirken, -GI eki ile birlikte o bağlllığa yönelten duygu anlamına gelmiştir.

\begin{tabular}{|c|c|}
\hline & \\
\hline eliDE Dil ve Edebiyat Araştırmaları De & E Journal of Language and Literature Studies \\
\hline 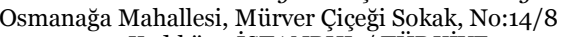 & Mahallesi, Mürver Çiçeği Sokak, No:14/8 \\
\hline Kadıköy $-\mathrm{I}$ & ISTANBUL / TURKEY 34714 \\
\hline $\begin{array}{r}\text { e-posta: editor } \\
\text { tel: }+905057958124,+9\end{array}$ & $\begin{array}{l}\text { editor@rumelide.com, } \\
\text { +90 505 7958124, +90 } 2167730616\end{array}$ \\
\hline
\end{tabular}


5.“... saygmnn şanlı bir abidesi gibi, uzun bacaklarını üzerinde dikiliyordu.” (BİS, s. 12)

Saymak fiili, bu örnekte birine değer vermek anlamında kullanılmıştır. -GI eki de alarak birine karşı değerli, üstün, özenli davranmaya iten sevgi duygusu anlamı vermektedir.

6.“Bütün bu bulgular, onun güvenilir biri olduğunu gösteriyordu, bu yüzden ona güvenmemeye karar verdim.” (BİS, s. 12)

-GI eki, bir şeyin ortaya çıkarma işi ve bunun sonunca elde edilen şey anlamı vermektedir.

7.“Doğrusu Romain’in bilgi ve görgüsüyle büyülendiğim kadar...” (BİS, s. 12)

$\mathrm{Bu}$ ek, bilgi kelimesine, öğrenme, araştırma yoluyla elde edilen gerçeklik, olgu anlamı verirken; görgü kelimesine ise, toplum içinde uyulması gereken kurallara uyan, saygılı ve ince davranışlarda bulunan kimse anlamı vermektedir.

8.“... hiçbir kitaba girmemiş, belki de hiçbir zaman girmeyecek olaylar, olgular, savlar, antisavlar...”(BİS, s. 31)

-GI eki, olmak fiiline, bir olayın dayandığı sebepler veya bu olayın sonunda elde edilen sonuçlar anlamını ifade etmektedir. Olan, var olan bir şeyin sonucu gösterilmektedir.

9.“...Floransa dibasından eteğinin desenleri kadar coşkulu bir kar sevincine dönüştürerek...” (AN, s.1)

Coşmak fiili, tek başına "duyguları güçlü bir şekilde dışa vurmak" anlamına gelmektedir. -GU eki ile birlikte, o güçlü duygu hali içerisine girme, büyük heyecan duyma" anlamlarını ifade etmektedir. -lI ekini de alarak, anlam daha pekiştirilmiş ve o eylemin artık harekete döküldü, o şekilde davranış gösterdiği belirtilmektedir.

\section{-GIn, -GUn:}

Daha çok oranda geçişsiz, daha az oranda da geçişli fiillere gelen ek, işlev bakımından fiilin gösterdiği işin tamamlanmış olduğunu bildiren sıfatlar türetmiştir. Bu işleviyle ek -mIş/ -mUş ad fiiline denk sayılabilir. Ekteki anlam aşırılığı da buradan kaynaklanmış olmalıdır. Yalnız az-, bez- gibi geçişsiz fiillere eklenen ek, azgın "azmış", baygın "bayılmış", bezgin "bezmiş" anlamlarını verdiği halde, geçişlilere eklendiğinde edilgenliğe dayanan bir tamamlanmışlık bildirir: gergin "gerilmiş", üzgün “üzülmüss", yorgun "yorulmuş” vb. (Korkmaz, 2009,s. 81; Ergin, 2004, s.189). Fiillere psikolojik hal, huy, alışkanlık, bitmişlik anlamları vermektedir.

\section{1.“... kibar bir kadını bile azgmn bir hayvana çevirecek kadar...” (SER, s. 10)}

Azmak fiili, taşkınlıkta ileri gitmek anlamına gelmektedir. Azgın kelimesi türetilirken -Gın eki, fiilin bildirdiği işin yapılmış olduğu göstermektedir. Azgın bir hayvan benzetmesi ile çok hareketli, taşkın, sinirli bir şekilde etrafa saldıran kişi ifade edilmektedir. Azmak fiilinin harekete döküldüğü gösterilmektedir.

2.“...ne kadar üzüntülü bir durumda olduğu gösteren baygın gözleriyle...”(SER, s. 46)

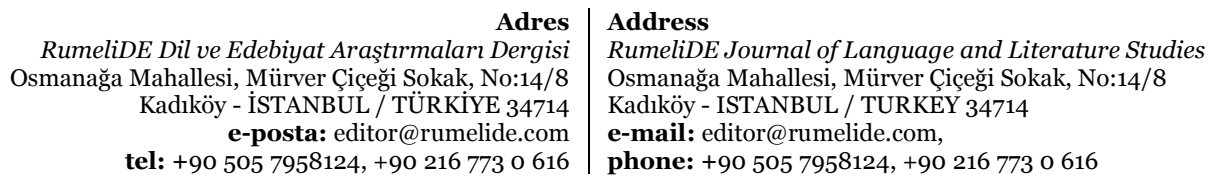


Baymak fiili tek başına kullanıldığı zaman can sıkıntısı vermek, bunaltmak anlamında kullanılır. -GIn eki baymak fiiline kendinden geçmiş olan, bayılmış anlamı vermektedir. Cümle içerisinde baygın kelimesinin kullanımına bakıldığı zaman, süzgün, hafif kısık bakmak anlamını ifade etmektedir.

3.“...ă̆ızlarında sakız, çıplak ayaklarında nahıla gelen yetişkin kızlar...” (KY, s.22)

-GIn eki, yetişmek fiilin bildirdiği işin tamamlanmış olduğunu göstermektedir. Yetişme işi bitmiş, büyümüş, belli bir olgunluğuna erişmiş olma anlamı ifade edilmektedir.

4."Bilhassa siyah, ince, fakat çok keskin kaşlarmın gölgelediği gene simsiyah ve iri gözleri...” (KY, s.35)

Kesmek fiili bu cümlede mecaz anlamında kullanıldığ görülmektedir. -Gın eki ile türetilerek yine gerçek anlamı dışında bir ifade söz konusudur. Keskin kelimesi, çok iyi kesici anlamına gelirken cümle içerisinde, çok sert, etkili, çizgileri belli olan bir kaş anlamını bildirmektedir.

5.“Keskin ve gür bir sesi, kandırıcı bir mantığı vardı.” (KY, s. s.97)

Bu cümledeki keskin kelimesi de yine mecazi bir anlamı ifade etmek üzere çok etkileyici, net bir ses anlamını bildirmektedir.

6."Muazzez”in etrafiyla bu kadar az alakadar olmaya başlaması ve rüyada yaşar gibi süzgün duruşları...” (KY, s.198)

Süzmek fiili de yine cümlede mecaz anlamı ile kullanılmıştır. Birini inceleme anlamına gelen süzmek fiili, -GIn eki alarak bu anlamından başka zayıf ve bitkin anlamı ile ifade edilmiştir. Süzgün kelimesi, hayattan kopuk, zayıf düşmüş, dalgın anlamlarında kullanılmaktadır.

7.“...seçkin olmaktan çok, birer suçlu, birer özürlü hissediyorduk kendimizi karşısında.”(BİS, s. 18)

-GIn eki, seçmek fiiline benzerleri arasında nitelikleri yüksek olan, özel, üstün kimse anlamı vermektedir.

8."Ben size hiç fena esir gösterir miyim, Paşazadem, şunlara bir bakın, cennet kaçkm huriler.” (AN, s.11)

Kaçmak fiili, bir yerden ayrılmak, kendini göstermemek anlamına gelmektedir. Bu ekle birlikte, insana özgü bir davranış haline getirilmiş ve cennet kaçmış ya da cennetten gelmiş gibi anlamlarını bildirmektedir.

9.“Çünkü o bakış idi ki sonu yangina çıkacak...”(AN, s. 15)

Yanmak fiili, sözlükteki ilk anlamına göre, “ateş durumuna geçmek”tir. Cümle içerisinde -Gin ekini alarak, bakışların çok etkili olduğu, karşısındakini cezbedecek, içini yakacak şekilde olduğu ifade edilmektedir.

10."Şair, işte o anda, dakikalardır damlayıp duran fenerin kzzgın yağından elinin yandığım hissetti.”(AN, s. 31)

\begin{tabular}{|c|c|}
\hline & \\
\hline eliDE Dil ve Edebiyat Araştırmaları De & E Journal of Language and Literature Studies \\
\hline 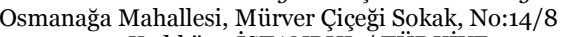 & Mahallesi, Mürver Çiçeği Sokak, No:14/8 \\
\hline Kadıköy $-\mathrm{I}$ & ISTANBUL / TURKEY 34714 \\
\hline $\begin{array}{r}\text { e-posta: editor } \\
\text { tel: }+905057958124,+9\end{array}$ & $\begin{array}{l}\text { editor@rumelide.com, } \\
\text { +90 505 7958124, +90 } 2167730616\end{array}$ \\
\hline
\end{tabular}


Kızgın kelimesi, tek başına bir ruh halini veya sinirli olma durumunu gösterirken cümle içerisinde fazla ısınan, yakacak derecede olan anlamı gösterilmektedir.

\section{$-\mathbf{I},-\mathbf{U}$ :}

Genellikle fiilin ifade ettiği anlamda, olanı, yapanı ve yapılanı bildiren bir ektir (Vural ve Böler, 2012, S.174).

1.“... eğitim ve beceri yerine geçen kötü huyları ve hileciliklerini gösteren...”(SER, s.51)

Beceri kelimesi, -I eki alarak bir işi başarma, elinden iş gelme durumu anlamında kullanılmıştır. Fiilin kök anlamından yetenek anlamına geçmesini bildirmektedir.

\section{2."Kendi yaznsıyla yazıll.” (VYS, s.13)}

Yazı kelimesinde, -I eki, fiilin ifade ettiği işin yapılmış olduğunu göstermektedir. Yazmak eylemi, henüz ortaya bir sonuç çıkarmamış, devam eden bir süreç söz konusu söz konusu olmuşken yazı kelimesi, yazma işi, ortaya çıkan semboller olarak değerlendirilebilir.

3.“...vücut güzelliği ve ölçülerine, terbiye ve ahlaklarma hayran oluyor inancindadırlar.” (SER, S.52)

-I eki, fiilin ifade ettiği anlamda yapılan anlamı vermektedir. Ölçü kelimesi, bir şeyi kendi biriminde oranlayarak değerlendirme anlamına gelmektedir. Bu cümlede ölçü kelimesi, vücudun düzgün bir fiziği sahip olduğu, her bölgenin birbiriyle orantılı bir durumda olduğu belirtilmektedir.

\section{4.“Eliyle ölüleri gösterdi.” (KY, s. 9)}

-I eki, ölü kelimesine ölmek fiilin ifade ettiği anlamda tamamlanmış, bitmiş anlamı vermektedir. Ölü, artık yaşam belirtisi olmayan, hayatı sona eren bir kimse olarak belirtilmiştir. Ölmek fiilinin bir kimseye verilmiş ismi olarak nitelendirilmiştir. Kök ile anlam ilişkisi devam etmiştir.

\section{5.“Gece yarmsından sonra geliyor, şafakla beraber gidiyordu.” (KY, s. 84)}

Yarmak fiili, bir şeyi bölüp ayırmak anlamına gelmektedir. -I eki alarak mecazi bir anlam ifade etmektedir. Gece yarısı, gecenin ilerlemiş saatleri, güneşin doğması ile batması arasındaki süreyi ifade etmektedir.

6."Dans etmiş, şarkı söylemiş, büyük babaannesinin cinsel anılarm anlatmıştı son olarak da." (BİS, s. 37)

Anmak fiili, birini veya bir şeyi hatırlamak anlamına gelmektedir. -I eki alarak geçmiş var olmuş bir olayın hafızada bıraktığı iz, hatıra anlamına gelmektedir. -I eki burada, unutulmayan, tekrar gündeme gelen bir olayı nitelendirmiştir.

7.“Özellikle bizler gibi, yürekleri en çok kendi beğenisi ve aşkıyla yanan...” (BİS, s. 45)

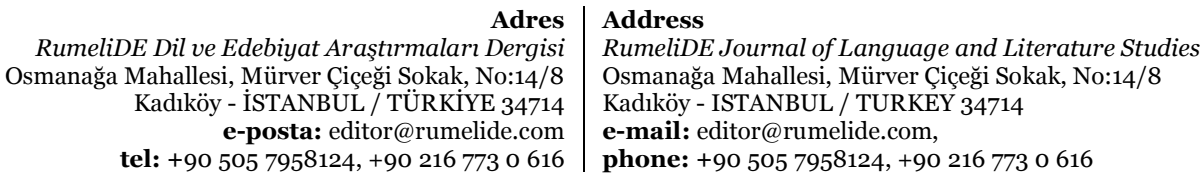


Beğenmek fiili hoşa giden anlamında kullanılırken, -I eki alarak yine kök anlamından farklı olmaksızın güzel veya çirkin algısını ayırt etme anlamında kullanılmıştır. Kendi zamiri ile birlikte cümle içerisinde, kendine ait bir güzel veya iyi algısı olma anlamı taşımaktadır.

8.“...Hayal Banu onun gerçekten de içi dışı su gibi duru, temiz ve berrak bir kız olduğunu gördü.” (AN, s. 10)

$\mathrm{Bu}$ ek, durmak fiilinden, arınmış, temiz kalpli, saf, içi dışı aynı olan anlamında duru kelimesini türetmektedir.

9.“...insan, yanlışın ve yalanın, çirkinin ve kötünün, adaletsizlĭgin ve haksızlı̆ın, zorbah̆ğın, sömürünün karşısında olmahdır.” (FÖ, s. 15)

Sömürmek fiili, bir devletin veya bir kişinin karşı taraftan haksız çıkar sağlaması anlamına gelirken, sömürü kelimesi, bu işin yapılması anlamını bildirmektedir.

\section{-IcI, -UcU:}

Türkçede eskiden beri kullanılan çok işlek fiilden isim yapma eklerinden biridir. Yapan, eden anlamına gelen isimler ve sıfatlar yapar (Vural ve Böler, 2012, s.174). Fiili, o işi süreklilik anlatımıyla yapan, yapma yetisine sahip anlamı vermektedir.

\section{1.“Özel burslu seçilmiş öğrenci.” (BİS, s.11)}

-IcI eki, fiili bildirdiği işi sürekli yapan, meslek veya uğraşı haline getiren anlamı vermektedir. Öğrenci kelimesi, öğrenmek fiilinden türemiş, öğrenme işini yapan, meslek edinen kimse anlamına gelmektedir. Fiildeki hareketi, başarıyla yapma anlamı yüklemektedir.

2."Keskin ve gür bir sesi, kanderzen bir mantığı vardı.” (KY, s.97)

-IcI eki, bu örnekte o işi yapan kimse anlamı vermektedir. Kandırmak fiili, -IcI eki alarak kandırma işini yapan veya o işi yapma yetkisini gösteren kimse anlamları yüklenmiştir. Bir alışkanlık anlamı yüklemektedir. Cümle içerisinde aklı veya zekâsıyla kandırma işini yapan, bu şekilde mantık kuran bir durum ifade edilmiştir.

3.“... her zaman yaknç bir güneşin altında kül olmuş...” (SER, s.98)

-IcI eki fiilin ifade ettiği anlamdaki özelliği üzerinde taşıma anlamı vermektedir. Yakıcı kelimesi, yakma özelliğine sahip anlamı bildirmektedir. Fiildeki hareketi süreklilik anlamı vermektedir.

\section{4. “Ama öyle senin bildiğin gelişlerden değil, adeta şöyle görücüye gelir gibi bir şey!” (KY, s. 50)}

Görmek fiili, -IcI eki ile birlikte kök anlamının verdiği görme işini yerine getirmektedir. Ancak görücü kelimesi, Türk kültüründe evlenmek isteyen bekâr bir erkek için kız görmeye veya bakmaya giden kimse anlamina gelmektedir.

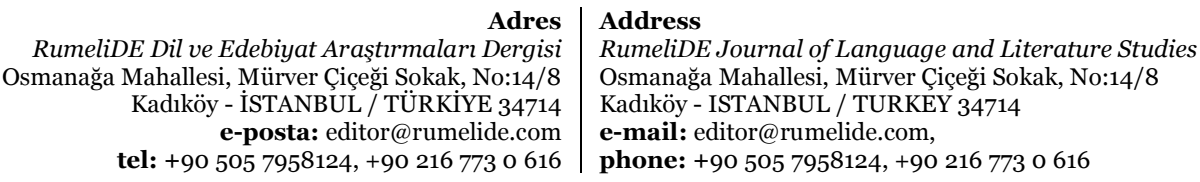




\section{$-(\mathrm{I}) \mathbf{k},-(\mathrm{U}) \mathbf{k}$ :}

Genellikle olanı ve yapılanı karşılayan sıfatlar ve isimler yapan bir ektir (Vural ve Böler, 2012:174; Ergin, 2004:188). Fiillere yapılmış, bitmiş anlamı vermekte veya yapılmış, tamamlanmış bir sonucunda geriye kalan, eşya, alet,-mIş ve -Il-mIş ekinin anlamını ve soyut fiillere somut anlam vermektedir.

\section{1.“Kararl, donuk bir sesi vardh.” (BİS, s.37)}

-(I)k eki, fiilin ifade ettiği anlama mecazi bir anlam yüklemiştir. Donuk kelimesi ile soğuk, canlı olmayan, durgun, duygusu belli olmayan bir anlam ifade edilmiştir.

2.“Ylkılmış, harap olmuş, yitik emellerin ve ümitlerin mekâmı olan...” (SER, s.20)

Yitirmek fiili, bir şeyi veya bir kimseyi kaybetmek anlamına gelirken; yitik kelimesi, kaybedilen şeydir. -(I)k eki, fiillin ifade ettiği şeyi gösteren ismi bildirmektedir. Cümle içerisinde de yine kaybedilmiş emel ve ümitler belirtilmiş ancak önceden var olan hayallerin yerine gerçekleşmemesi sonucunda umutsuzluk ifade edilmiştir.

3.“Ashında, soluk alp vererek, yaşıyormuş gibi oyunu oynayan milyarlarca insana hakaret ettiğini...”(BİS, s.35)

Soluk kelimesi, nefes, alınan hava anlamına gelmektedir. -(I)k eki, fiilin bitmiş halini bildirmektedir.

\section{4. “Büyükler ikişer kişilik kayık salıncaklara biniyorlardı.” (KY, s. 30)}

-(I)k eki, kaymak fiiline bir araç ismi anlamı yüklemektedir. Kayık, yayvan biçimde olan küçük tekne anlamına gelmektedir. Cümle içerisinde ise, salıncakların kayık şeklinde olduğu belirtilmektedir.

5.“Üç esir ile birlikte erkek elbiseleri giydirilerek Akbıyık'tan bir kayı̆̆a, oradan da...”(AN, s. 15)

Bu örnekte ise, kayık kelimesi bir benzetme aracı olarak değil, kendi anlamında, yayvan şeklinde olan küçük tekne anlamında kullanılmaktadır.

\section{6. “Seçkin öğrencilerin konuk edildiği orta blok on katlıydı ve adı kısaca J idi.” (BİS, s. 19)}

Konmak fiili, tek başına kullanıldığında bir yerde kalmak ve geçici bir süre yerleşmek anlamına gelirken; -(I)k eki konmak fiilini geçici yerleşme anlamına bağlı olarak misafir anlamı vermektedir. Konuk kelimesi de, bir yere geçici veya kısa süreli olarak giden misafir anlamına gelmektedir.

7.“Uyku girmeyen gözlerinden yaşlar döktü ve zaman zaman heçkarıklarmı tutamayarak...” (AN, s.11)

Hıçkırmak fiili, sözlükteki ilk anlamına göre, "boğazdan çıkan ses” demektir. Bu eki alarak ve cümle içerisinde "ağlamak, ağlayarak çıkarılan ses" anlamına gelmektedir.

\footnotetext{
Adres $\mid$ Address

\begin{tabular}{r|l} 
Adres & Address \\
RumeliDE Dil ve Edebiyat Araştırmaları Dergisi & RumeliDE Journal of Language and Literature Studies
\end{tabular} Osmanağa Mahallesi, Mürver Çiçeği Sokak, No:14/8 Osmanağa Mahallesi, Mürver Çiçeği Sokak, No:14/8 Kadıköy - İSTANBUL / TÜRKIYE 34714 Kadıköy - ISTANBUL / TURKEY 34714 e-posta: editor@rumelide.com e-mail: editor@rumelide.com, tel: +90 505 7958124, +90 2167730616 phone: +90 505 7958124, +90 2167730616
} 


\section{8.“...akıp giden hareketli ve savruk hayatına...”(AN, s.71)}

Savurmak fiili, saçmak, fırlatmak anlamlarına gelirken, -(U)k ekini alarak "düzensiz, belirsiz, nasıl ve ne yapıldığı belli olmayan ve oradan oraya savrulan” anlamlarında savruk kelimesini türetmektedir.

9.“Oysa, insan, geçmiş ve gelecek zamanı, şimdiki zamanıyla birleştirdiği, kaynaştırdığı ölçüde yaşayan yarathktor.” (FÖ, s.28)

Yaratmak fiili, olmayan bir şeyi var etmek anlamı taşırken, bu eki alarak, yaratılmış olan anlamında yaratık kelimesini türetmektedir. Cümle içerisinde, Allah tarafından yaratılan insanı ifade etmektedir.

\section{$-(\mathbf{y}) \mathbf{I p} /-(\mathbf{y}) \mathbf{U p :}$}

"Ya da suratınızı asıp onu görmezden gelirsiniz." (BİS, s.20)

-(y)Ip eki zarf-fiil olmakla birlikte fiillere gelerek onları haline getirmektedir. Surat asmak fiili bu eki alarak cümle içerisinde yüklemin nasıl yapıldığını anlamlandırmıştır. Ayrıca surat asmak ile görmezden gelmenin aynı zamanda yapıldığını bildirmektedir.

“... asil bir hanımefendiydi ve çok uzun yaşadığını söyleyip durduğu hayatının son yıllarında...” (AN, s.2)

$\mathrm{Bu}$ ek, söylemek fiiline süreklilik anlamı vermektedir. Cümle içerisinde bir konunun tekrar tekrar anlatıldığ 1 ifade edilmektedir.

\section{-iken/ -ken:}

Ünlü uyumu kurallarından kaçınan bu ek, $i$ - ek-fiilinin zarf biçimidir. Ünsüzle biten ad ya da ad niteliğinde fiil şekillerinden sonra $i k e n$ ve çok kez de $i$ - ek fiilinin erimesiyle -ken biçiminde kullanılır. Ünlüyle biten adlardan sonra eriyen $-i$ filinin yerini $-y$ - koruyucu ünsüzü alır (Korkmaz, 2009, s. 88). Fiilin gösterdiği işin aynı zaman kesitinde yapıldığı anlamı vermektedir.

1.“...ilk karlara saplanan ölüm ıssızlı̆̆ şehrin üstünde bir kâbus heybetiyle dalgalanurken...”(AN, s.1)

Dalmak fiili, sözlükteki ilk anlamına göre "suya atlamak, denize girmek" anlamlarına gelmektedir. -gA ekini alarak, büyük ve geniş bir duygunun ortaya çlkmasını bildirmektedir. -ken ekini de alarak, bu anlam pekiştirilmiş, cümle içerisinde ölüm hissinin içinde bulunulan anda her yeri sardığı, büyük bir alana yayıldığı ifade edilmektedir.

2.“...üstelik de dünyanın dört bir yanında umumi harbin çı̆̆lıklarl yankalanirken, torunuyla vakit geçirmekten ve onun meşk ettiği hatıralar anlatmaktan gayrı lezzet aldığı bir zamanın kalmadığını düşünürdü.”(AN, s.2)

-ken eki de fiilin bildirdiği işle aynı zaman kesitinde yapılan başka bir işe “-dığı zaman” anlamı vermektedir. Savaş sesleri yankılandığı zaman o da torunları ile vakit geçirdiği ve hatıralarını anlattığı aynı zaman dilimi ifade edilmektedir.

\begin{tabular}{r|l} 
Adres & Address \\
RumeliDE Dil ve Edebiyat Araşțrmaları Dergisi & RumeliDE Journal of Language and Literature Studies \\
Osmanağa Mahallesi, Mürver Çiçeği Sokak, No:14/8 & Osmanağa Mahallesi, Mürver Çiçeği Sokak, No:14/8 \\
Kadıöy - İSTANBUL / TÜRKIYY 34714 & Kadıköy - ISTANBUL / TURKEY 34714 \\
e-posta: editor@rumelide.com & e-mail: editor@rumelide.com, \\
tel: +90 505 7958124, +90 216773 o 616 & phone: +90 505 7958124, +90 216773 o 616
\end{tabular}


3."Yani, 2000 miladi yılına girerken, bir zemberekten boşanmışçasına sökün eden değisşimler..." (FÖ, s.19)

Girerken kelimesi, gelecek olan zamana az bir zaman kala anlamını ifade etmektedir. Cümle içerisinde, 2000 yılına girmeye yakın veya yeni girilmiş olmayı bildirmektedir.

\section{-(I)m, -(U)m:}

Fiilden isim yapma eklerinin çok işlek olanlarından biridir. Tespit edilen anlamlar örnekler üzerinden aşağıda gösterilmiştir.

\section{1.“... oğlunun gençlik e ĕgilimleri ve hayalleri içinde kaybetmeye çalıştığı geleceğini...” (SER, s.63)}

-(I)m eki, eğilmek kelimesine bir şeye yönelme, yönelim, meyil anlamları vermektedir. Cümle içerisinde gençliğin verdiği duygular ile hareket etme anlamını ifade etmektedir. Eğilme fiili tek başına kullanılsaydı eğer bir şeyi ele alma anlamında kullanırdı ancak -(I)m eki ile birlikte yönelme anlamını bildirmektedir.

\section{2.“Aman Tanrm, ne korkunç bir ikilem olmah bu!” (BİS, s.45)}

İkilem kelimesi, istenmeyen iki durum ile karşı karşıya kalma anlamı vermektedir. İki seçenekten birini seçme zorunluluğu olan kişi ünlem cümlesi içerisinde sitemini dile getirmektedir. İkilem kelimesi, cümle içerisinde bu duygu anlamını ifade etmektedir.

3. "Erkek olsaydım, albenisinin renkli rüzgârına mutlaka takılır, uzak bir uçuruma düşene dek uçardım onunla."

Uçurmak fiili tek başına yüksek bir yerden aşağıya doğru inmek anlamı taşırken -(I)m eki ile anlam değişikliğine uğramıştır. Uçurum kelimesi, denize kıyısı olan veya karada bir dağın kenarında yüksekte olan kısım anlamına gelmektedir.

\section{4. “Ya şimdi, her gün Allah’tan ölümümü istemekte haklı değil miyim?” (VYS, s.14)}

Bu ek, ölüm kelimesine hayatı sona erdirmek anlamı vermektedir. Cümle içerisinde artık hayatta kalmak istememe, ölümü isteme anlamı ifade edilmektedir. Bıkmışlık, tükenmişlik hissi ölüm kelimesi üzerinden verilmektedir.

5. "Yusuf bu yarm ve manasız cümleleri tamamıla anlamış gibi cevap verdi.”(KY, s.119)

-(I)m eki burada ölçü anlamı vermektedir. Yarım kelimesi, bir bütünün ikiye ayrılması anlamına geldiği gibi, cümle içerisinde bakıldığı zaman eksik kalmış anlamı ifade edilmektedir.

6. “... e ĕgitim ve beceri yerine geçen kötü huyları ve hileciliklerini gösteren küçük siyah gözleriyle...” (SER, s. 51)

-(I)m eki, eğitmek kelimesine gelerek uzun süreli yapılan bir işi anlatma ifadesi vermektedir. Eğitmek fiili, belli bir konuda yetiştirme anlamı taşırken, eğitim kelimesi de kök ile aynı anlama gelmesine rağmen -(I)m ekiyle bu eylemin uzun süreli bir iş olduğu bildirilmektedir.

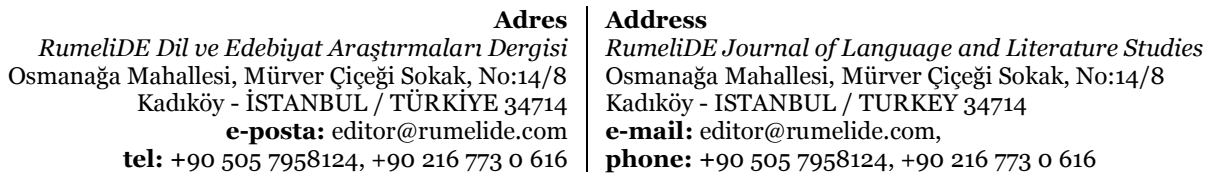


7. “...sekiz dönüm bă̆ bahçe içinde bir kanarya aşiyanını andıran...” (AN, s. 1)

Dönmek fiili, "kendi veya bir şeyin etrafında hareket etmek" anlamı g gelmektedir. Bu eki alarak, bir alan ölçüsü anlamına dönüşmektedir. Cümle içerisinde, sekiz bin metre kare bir alan ifade edilmektedir.

8. "Ertuğrul'un yolculuğa mukavemet edecek donanımı zayıf ise de güzelliği ve ihtişamı bu şerefli görev için pek uygundu.”

Donanmak fiili, giyinip kuşanmak, her yeri kaplamak anlamlarına gelirken, bu eki alarak gemi için gerekli tüm malzemelerin hazır olması, var olması anlamına gelmektedir. Fiilin oluş şeklinden olmuş bitmiş, tamamlanmış anlamını ifade etmektedir.

9. “...hep aşk üzerine nice nice konuşmalarla ve o konuşmalara açılım getiren nice hikâyelerle geçmiş...”(AN, s.116)

Açılım kelimesi, cümle içerisinde bu eki alarak konuşmaları daha akıcı ve anlaşılır hale getirmek anlamı vermektedir. Önsöz niteliği taşımaktadır.

10. “... bu hikayeyi zihnimde kaç farkl biçimde yeniden tamamladiğımı şimdi ben bile sayamıyorum.”(AN, s. 238)

Biçmek fiili, belli bir şekil vermek anlamında iken -Im ekini alarak, farklı düşünce tarzı veya bakış açısı, düşüncelere tekrar tekrar şekil verilmiş anlamında biçim kelimesini türetmektedir.

11. “Dinlenişini ve athlımm zamanlayamayan toplumlar için, gelecekler karanlıktır.” (FÖ, s. 10)

Atılmak fiili, bir işe girişmek anlamına gelmektedir. -Im eki alarak, bu işin yapılması anlamını bildirmektedir. Cümle içerisinde, bir devletin ilerlemesi için yapılan hamle, ilerleme çabası olarak ifade edilir.

12. “Ne kurımlar, ne zulümler, ne aldanışlar gördük, bu, yüzyılların kar gecesinde!” (FÖ, s.12)

Kırmak fiili, -Im ekini alarak, katletmek, öldürmek anlamına gelmektedir. Cümle içerisinde haksız yere öldürülen, zulüm edilen insanlar ifade edilir.

13. "...bir ruh devrimiyle insanlarn büyük kayıplara uğramadan "büyük ve yeni medeniyet birleşimi” dönemine geçmelerini diliyoruz.” (FÖ, s.65)

Devirmek fiilinden türetilen devrim kelimesi, hızlı ve köklü bir değişiklik anlamına gelmektedir. Cümle içerisinde, insanın köklü bir düşünce ve inanç değişimi ifade edilir.

-mA:

Fiil ve fiilimsileri olumsuz şekillerini yapmak suretiyle genişletir (Banguoğlu, 2011, s.264). Eklendiği fillerin anlamını değiştirmeyip kök anlamını devam ettirmiştir veya olumsuzluk anlamı vermiş ve bazı fiillerde kalıcı isim oluşturmuştur.

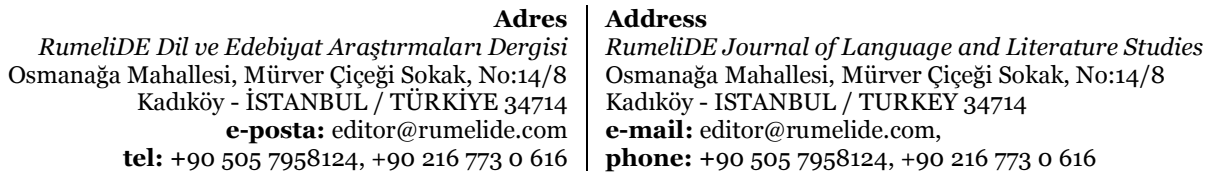

tel: +90 505 7958124, +90 2167730616

phone: +90 $5057958124,+902167730616$ 
1.“... bu yüzden ona güvenmemeye karar verdim.”(BİS, s. 12)

-mA eki, güvenmek fiiline gelerek fiilin ifade ettiği duygunun adı anlamı vermektedir. Birinci -mA eki, kök ile aynı anlamda kelime türetirken, ikinci -mA eki, kelimeye olumsuzluk anlamı vermektedir.

2. “Örneğin, balık ezmesini sütle karıştırarak hazırlanan balık köftesi...” (BİS, s.19)

-mA eki bu örnekte de fiile yemek anlamı vermektedir. Herhangi bir yiyeceğin ezme türü şeklinde yemeği olduğu bilinmektedir. Cümle içerisinde ise, balık ezmesi yemeği ifade edilir.

3. "Müslümanlara düşman olup kin duyan bathlllarda da, bu yeni doğuş ve ilerleyişe bir özenme, imrenme belirdi.” (FÖ, s.29)

Özenmek ve imrenmek fiilleri, beğenilen bir şeye benzemeye çalışmak anlamlarına gelirken, -mA eki ile fiilin bildirdiği eylemi yapma işi anlamına gelmektedir. Cümle içerisinde, özenilen ve imrenilen bir şeyi ifade etmektedir.

\section{-mAcA:}

-mA fiilden ad türetme ekiyle -cA addan ad türetme ekinin kaynaşmasından oluşan bu birleşik fiildir. Fiillere eklenerek oyun, eşya ismi anlamı vermesinin yanında ifade edilen işin nasıl ve ne şekilde oluştuğu anlamını vermektedir.

1.“Bulmacayı çözmüş yaramaz çocuk gibi baktı yüzüme...”(BİS, s.49)

Bul fiili, -mAcA ekini alarak yine bulmaya dayalı bir oyun anlamı kazanmıştır.

2.“...koltuklarm altları çekmece olarak kullamılabiliyordu.”(BİS, s.17)

Çekmek fiili de yine -mAcA ekini alarak, kök anlamına bir gereç kavramı oluşturmaktadır. Çekmece, içine herhangi bir eşyanın dışarıya çekilerek açılan bölümü anlamı taşımaktadır.

3. “...ona kızının ağzından düzmece mektuplar yazıp, düzmece adreslere cevaplar istemişs...” (AN, S.285)

-mAcA eki, düzmek fiilinden, gerçek olmayan, sahte anlamında düzmece kelimesini türetmektedir. Cümle içerisinde, yalan mektup, sahte adres, hile ile oluşturulmuş anlamı ifade edilmektedir.

4. "Bir vahşet ki, bunu sadece bir "çevre" problemi saymak, insantn en büyük aldatmacası." (FÖ, s.128)

Aldatmak fiili, kandırmak anlamına gelmektedir. -mAcA ekini alarak, fiilin ifade ettiği eylemi harekete veya davranışa dökme anlamına dönüşmektedir. Aldatmaca kelimesi ile, cümle içerisinde, insanın kendi kendini kandırması, gerçek olmayan bir şeye inanması anlatılmaktadır.

-mAdAn < -mAdIn:

Fiillere kök anlamını değiştirmeden olumsuzluk anlamı vermektedir.

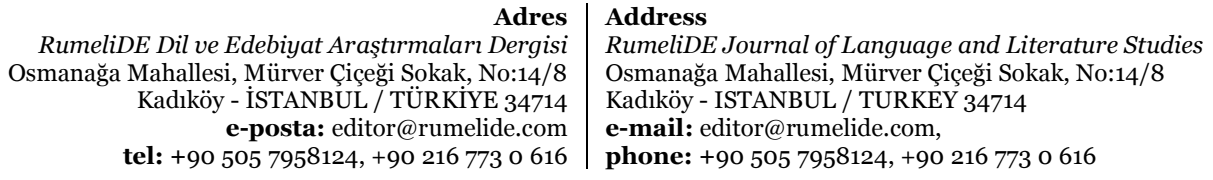

tel: +90 $5057958124,+902167730616$ 
1.“... bütün sıcaklı̆̆ıı ona vermiş, sırtına vuran gecenin ayazına aldırmadan, parmaklarının hissetmeyecek derecede üşüdüğünü bilmeden ve nemli gözlerini hiç kapamadan sabahın ışıklarına ulaşmıştı.”(AN, s.95)

$\mathrm{Bu}$ ek, kelimelere -maksızın anlamında olumsuz anlamlar vermektedir. Aldırmaksızın, bilmeksizin ve kapanmaksızın ile aynı anlama gelmektedirler.

-mAk:

İsim-fiil eki olan bu ek, fiilin kök anlamını değiştirmez ancak bazı fiillerde kalıcı isim oluşturarak anlam değişikliğine yol açmıştır.

1. "Kızlar bu evde geceleri bir odaya toplanır, birbirleriyle konuşurlard,; fakat çok gülmek, Çerkezce konuşmak yasaktı.” (SER, s. 7)

-mAk eki, bütün fiillere gelerek onları kök ile aynı anlamda isim haline dönüştürmektedir. Anlamca bir değişiklik yapmayarak fiilin ifade ettiği anlamda yeni bir kelime türetmektedir. Konuş-mak fiili de mAk eki ile birlikte yine bir düşünceyi sözlü olarak ifade etmek veya cümle içerisindeki anlamına göre konuşma dili olarak kullanma anlamlarına gelmektedir.

2. “Fakat akşam olduğu, yemek hazırlamak icap ettiği aklına gelince yüzü buruştu.” (KY, s.182)

“Sen bu vatanin ekmeğ ini yemedin mi?” (VYS, s. 63)

Bu tür örneklerde de -mAk ekinin fiil ile kalıplaşıp kullanımı söz konusudur. Ye-mek fiili -mAk eki alarak, karın doyurma işinden, yenmek için hazırlanan yiyecek anlamına gelmektedir.

Ekmek kelimesi de, undan yapılmış bir tür yiyecek anlamına gelmesinin yanında, cümle içerisinde yemek, aş, vatan sayesinde yararlanılan destek anlamlarında kullanılmaktadır.

3. "Biz İslam medeniyetinin çocuklar, bir "model" çizmek, yeni bir model üretmek zorundayız." (FÖ, s.108)

Çizmek ve üretmek fiilleri, kök ile aynı anlama gelmektedir. -mAk eki anlamda bir değişiklik yapmamasına rağmen türünü ve yapısını değiştirmektedir.

-mAklA:

Bu ek, -mAk ad-fiiliyle ile edatının kaynaşmasından oluşmuştur (Korkmaz, 2009: 96). Fiillere -mAk suretiyle veya $-\mathrm{mAk}$ amacıyla anlamı vermektedir.

1."Geminin tek sürgün memuru sayılan ve gemi mürettebat tarafindan ileri yaşında sürgüne gönderilmekle bir ayağı çukurda farz edilen Ebubekir Efendi...”(AN, s. 91)

-mAklA eki, -mak suretiyle, -mak amaciyla anlamlarında kelimeler meydana getirmektedir. Gönderilmekle kelimesi, gönderilmek suretiyle veya gönderilmek için anlamlarını ifade etmektedir.

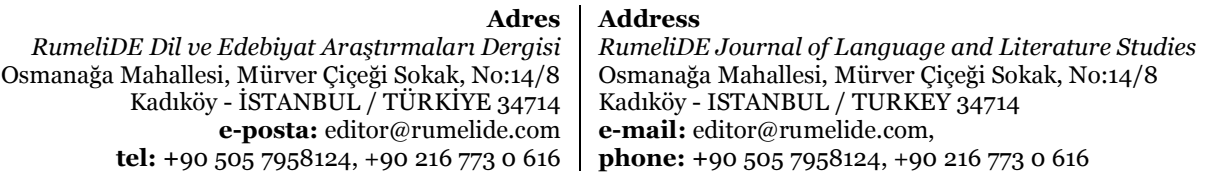

tel: +90 505 7958124, +90 2167730616 
-mAlI:

Eski Anadolu Türkçesinden Türkiye Türkçesine uzanan -mAlI eki, fiilden ad türeten -mA ekiyle -lI/ IU sıfat ekinin kaynaşmasından oluşmuştur(Korkmaz, 2009, s.96). Fiilin gösterdiği işi üzerinde nitelik olarak taşıyan anlamı vermektedir.

1. "Günde üç saat sürecek konferanslardan ve seçmeli tartışma bölümlerinden oluşan takvimimizi tamamlamamız yalnızca iki gün sürdü.” (BİS, s. 31)

-mAlI eki, seçmek fiiline gelerek, seçme özelliğini üzerinde barındıran anlamında seçmeli kelimesini türetmiştir. Seçmeli kelimesi, cümle içerisinde tartışma bölümlerinden isteğe bağlı olarak herhangi birini seçme, zorunlu olmayan anlamlarını ifade etmektedir.

$-\mathbf{m A z}$

Ergin'e göre ek, iki ekin birleşmesinden oluşmuştur: "Menfilik ifade eden bu ekin -ma-, -me- fiil yapma eki ile -z ekinden yapılmış olduğu açıktır.” (2004, s.197). Bazen tek bazen ikileme oluşturarak olumsuzluk anlamı vermektedir.

1.“Kalbim ya bilinmezlerde ya da mezarlar içinde gezer haldeydi.” (VYS, s. 75)

-mAz eki, bilmek fiili gelerek süreklilik ve olumsuzluk anlamı vermektedir. Bilinmez kelimesi, cümle içerisinde kalbin bilmediği bir yerde ve sürekli o bilinmeyen yerlerde gezer halde olduğu ifade edilmektedir.

2.“... Günnar gider gitmez bizlere fisıldadiğı kendi seçtiği adla Jeanne’nin seçilmiş, çok özel bir kadın olduğu hemen anlaşllyyordu.”(BİS, s.21)

Bu örnekte de -mAz eki, kendinden önce gelen -Ar eki ile birlikte çabukluk anlamı katmaktadır. Gider gitmez ikilemesi, cümle içerisinde gittiği an, çok süre geçmeden anlamlarında kullanılmıştır.

3. "Bir hayat... Krrk-elli yıllık bir hayat... -Kırk-elli yıllık değil, bitmez tükenmez olsun.-”(VYS, s. 93)

$\mathrm{Bu}$ örnekte de iki -mAz’lı anlatımın tekrarlanmasıyla anlam pekiştirilmek, vurgulanmak istenmektedir. Bitmesin veya tükenmesin kelimeleri de kullanılabilirdi ancak anlama istek değil kesinlik anlamı verilmek için bitmez tükenmez ifadeleri kullanılmıştır. Cümle içerisinde hiçbir zaman sona ermeyecek, sonsuza dek sürecek olan bir hayat ifade edilmektedir.

4. "...kendi zengin hazinesini küçümseyen bir insanın görüntüsüne benzer bir çıkmaza saplanıp kalmış durumda.” (FÖ, s.23)

-mAz eki, çıkmak fiiline de olumsuzluk anlamı vermektedir. Ancak çıkışı olmayan anlamından ziyade cümle içerisinde, çözüme ulaşılamayan veya elindekinin farkına varılamayan anlamları ifade edilmektedir.

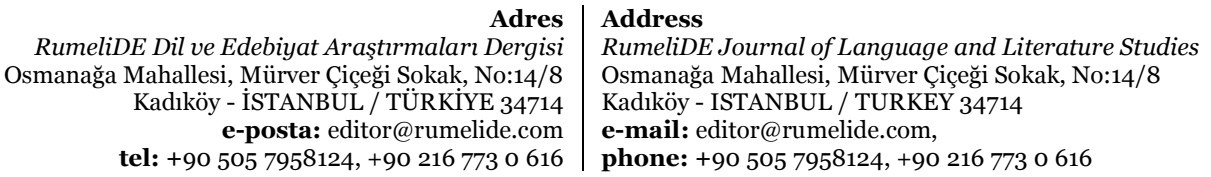




\section{mAzlIk:}

-mAz sifat-fiil ekinin soyut adlar türeten -lIk/ -lUk ekiyle genişletilmesinden olumsuzluk bildiren soyut adlar oluşmuştur (Korkmaz, 2009, s.99).

\section{1.“Vazgeçilmezlik?}

Vazgeçilmez olan...

Vaz-geç!..

Ah şu vazgeçilmezlik!" (BİS, s.46)

Bu ek kelimeye, olumsuzluk anlamı vermektedir. Cümle içerisinde kolay kolay bırakılamayan değerli bir şey ve bu vazgeçilmez olan şeyin bazen pişmanlık duygusu verdiği ifade edilmektedir.

2. "Umutsuzluk geleceği, umursamazhk geçmişi unutturur.” (FÖ, s.28)

Umursamak fiili, birini veya bir şeyi önemseme anlamına gelmektedir. -mAzlIk eki, bu fiile, olumsuzluk anlamı vermektedir. Umursamazlık, önemsememe, boş vermişlik anlamlarında kullanılmıştır.

\section{-mIş, -mUş:}

Öğrenilen geçmiş zaman sıfat-fiil ekidir. Geçmişte bitmiş, tamamlanmış işlere kesinlik anlamı vermektedir. Bu anlamı bazen ikileme oluşturarak bazen de kalıcı isim oluşturarak vermektedir.

1.“... usul usul karlaşmış saçları, fakat en önemlisi son derece soylu bir havası vardı.” (BİS, s.13)

Kırlaşmak fiili, beyazlamak, saçına ak düşmek anlamlarına gelmektedir. -mIş eki alarak geçmiş zaman anlamının yanında geçmişte bitmiş veya tamamlamış anlamı da vermektedir. Zaman içerisinde saçların beyazlaması anlatılmak istenmektedir.

2.“...öyle görmüş̧ geçirmiş, yatıştırıcı ve inandırıcı bir ses tonu vardı ki...”(BİS, s.21)

Burada da -mIş eki, görmek ve geçirmek fiillerine eklenerek geçmişte çok olay yaşamış, görgülü, deneyimli anlamları vermektedir.

3. “...toplumlarm hayatında sun’i olarak geçmişle ilişkiyi kesmenin bir netice veremeyeceği gerçeğidir.” (FÖ, s. 21)

-mIş eki, bazı fiillerle kalıplaşarak kullanılmaktadır. Geçmiş kelimesi de bunlardan biridir. Geçmiş kelimesi, bugüne göre geride kalmış zaman anlamına gelmektedir. Cümle içerisinde, toplumun tarihi, toplum için önemli zamanlar ifade edilmek istenmektedir. 


\section{-(I)mlI/ -(U)mlU:}

Fiilden -(I)m/ -(U)m ekiyle türetilmiş bazı adlar yalnız başlarına kullanılmayarak ve -lI/ -lU sıfat ekiyle de genişletilerek, -(I)mlI/ -(U)mlU birleşik ekli birer ad niteliği kazanmış görünüyor (Korkmaz, 2009, s.100). Fiilin bildirdiği hareketin niteliği veya özelliği üzerinde taşıma anlamı vermektedir.

1.“Bakıml, atletik bedeni, kendine gösterdiği özen ve saygının şanh abidesi gibi...” (BİS, s. 12)

Bu ek bakmak fiiline, kök anlamının ifade ettiği kendine özen gösteren, değer veren, dış görüşüne önem veren anlamları kazandırmaktadır.

\section{$-(I) n,-(U) n:$}

Genellikle fiilin ifade ettiği anlamda, yapanı, yapılanı, iş ve oluşu bildirir.

\section{1.“...dört kanal müzik yayın yapan mobilyah bir radyo vardı.” (BİS, s.17)}

Bu ek yaymak fiiline gelerek, fiilin bildirdiği anlamda yapılan işi ifade etmektedir. Cümle içerisinde insanlara radyo aracılığıyla sunulan bir müzik programı anlamı bildirilmektedir.

2. "O stralar komşumla ilgili tek sorunum, onun ne zaman ciddi, ne zaman şakacı, hatta dalgacı olduğunu çıkartamamamdı.”(BİS, s. 21)

Sorun kelimesi, -(U)n ekini alarak, üzerine düşünülmesi gereken bir problem anlamına gelmektedir. Cümle içerisinde, sıkıntı veren bir durum anlamında kullanılmaktadır.

\section{-tI, -tU, -(I)ntI, -(U)ntU:}

-tI/ -tU ekiyle, -(I)ntI/ -(U)ntU eki arasında yapı ve işlev bakımından bir ayrılık yoktur. -(I)ntI/ (U)ntU biçimiyle dönüşlü olmayan fiil köklerine türetme sırasında -n- ekinin eklenmesiyle bir dönüşlülük özelliği katılmıştır (Ergin, 2004, s.194). fiilin gösterdiği işin sonucu veya ürünü olan, tekrarlama ve süreklilik, kalıntı ürün, artık anlamı vermektedir.

1. “Dünkü sarsıntının korkunç etkisinden vücuduna ara sıra korkunç bir ürperme geliyor...” (SER, s.78)

$\mathrm{Bu}$ ek, fiilin gösterdiği işin sonucunda oluşan, bitmiş anlamı vermektedir. Sarsıntı kelimesi, sarsma sonucu oluşan titreme anlamına gelmektedir. Cümle içerisinde mecaz anlamında kullanılarak, beklenmedik olumsuz değişiklik anlamına gelmektedir.

2.“Bu Cuma gezintileri de mahalledeki çocuklarn pek mühim eğlencelerinden biri idi.” (KY, s.23)

Bu örnekte de -(I)ntI eki, fiile sürekli tekrarlanma anlamı vermektedir. Cümle içerisinde her hafta Cuma günleri yapılan gezmeler ifade edilmektedir.

3. “İçindeki bütün yıkmthlara, bütün kederlere rağmen başını yere eğmek istemiyordu.” (KY, s. 215)

\begin{tabular}{|c|c|}
\hline Adres & Address \\
\hline RumeliDE Dil ve Edebiyat Araşturmalar De & RumeliDE Journal of Language and Literature Studies \\
\hline smanağa Mahallesi, Mürver Çiçeği Sokak, No:14 & Osmanağa Mahallesi, Mürver Çiçeği Sokak, No:14/8 \\
\hline $\begin{array}{r}\text { Kadıköy - ISTANBUL / TÜRKIYE } 34714 \\
\text { e-posta: editor@rumelide.com } \\
\text { tel: +90 } 5057958124,+90216773 \text { o } 616\end{array}$ & $\begin{array}{l}\text { Kadıköy - ISTANBUL / TURKEY } 34714 \\
\text { e-mail: editor@ rumelide.com, } \\
\text { phone: +90 505 7958124, +90 } 216773 \text { o } 616\end{array}$ \\
\hline
\end{tabular}


Bu ek, kelime fiilin gösterdiği işin sonucu kalıntı ürün anlamı vermektedir. Yıkıntı kelimesi, yıkılan bir şeyden kalan parça anlamına gelirken, cümle içerisinde mecaz anlamı ile kullanılmaktadır. Ruhsal bakımdan çekilen acılar oluşan çöküş ifade edilmektedir.

\section{4. "Diğer insanlarm sıknthları veya üzüntüleri onun için önemsenmeyecek şeylerdi.” (SER, s.5)}

-(I)ntI, -(U)ntU eki, fiillere gelerek insan sağlığı veya huyu anlamında sıkıntı ve üzüntü kelimelerini türetmiştir. Sıkıntı, ruhsal yorgunluk, sorun anlamlarına; üzüntü, bir durum karşısında, bir durum sonucunda oluşan tedirginlik, keder anlamlarına gelmektedir.

\section{5. “...bütün ayrmthları binlerce kez anlatılsa bile aslında tamamen o ikisi arasında gizilidir.”}

Ayırmak fiili, bu eki alarak bir şeyi oluşturan bütün parçaların her biri, her bir öğesi, detay anlamını bildirmektedir. $\mathrm{Bu}$ ek, bir şeyi parçalara bölmek anlamından bölünen her bir parça anlamına getirmektedir.

\section{6. “...esir fiyatlarının iyiden iyiye düştüğü söylentisiyle...”(AN, s. 11)}

Söylemek fiili, tek başına bir duyguyu veya düşünceyi ifade etmek anlamı verirken, bu eki alarak, dedikodu, gerçek olmayan ifadeler veya bir kişinin söylediği bir sözün etrafa yayılması, ağızdan ağıza dolanması anlamında söylenti kelimesini oluşturmaktadır.

\section{7. “Sayda ile Singapur arasındaki onca stradan çalkantılar, tehlikeli firtınalar...”(AN, s. 116)}

Çalkantı kelimesi, fiilin ifade ettiği eylemin sonucu anlamında, deniz oluşan dalgalanmalar anlamını ifade etmektedir.

\section{8. “Her İslam ülkesinin ufkunda gulyabani görüntüleri.”(FÖ, s.12)}

Görmek fiili, göz yardımıyla var olan bir şeyi algılamak anlamına gelirken, -(U)ntU ekini alarak, gerçekte var olmayan ancak varmış gibi canlandırmak anlamına gelen görüntü kelimesini türetmektedir.

9. “...Isslam medeniyetinden kalan eski püskü eşyanın dökü̈ntülerini dahi antika değerinde görerek toplayıp götürüyor.” (FÖ, s. 30)

-(U)ntU eki, dökmek fiiline işe yaramayan, değersiz, arta kalan parça anlamı vermektedir.

$-\mathbf{r},-\mathbf{A r},-(\mathbf{I}) \mathbf{r} /-(\mathrm{U}) \mathbf{r}:$

Aslında geniş zaman sıfat-fiilleri türeten çok işlek bir ektir. Bazı kalıcı isimler oluşturmakla birlikte fiilin gösterdiği işi yapan, eden anlamı vermektedir.

1. "Beni zamanı geçmiş bir yazar olarak kaldırı, raflar arasına sakladıklarında, yalnızca adımı değiştirdim.”(BİS, s. 41)

Bu ek, fiilin bildirdiği işten, o işi yapan anlamında kelime türetmektedir. Yazar, yazma işini yapan, o işi meslek haline getiren kimse anlamina gelmektedir.

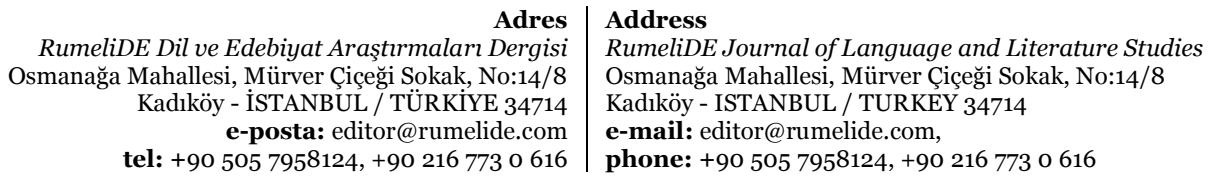


2. “...İslam düşünürleri, Müslümanın kimliğini ve kişiliğini...”(FÖ, s.124)

Düşünmek fiili, aklından geçirmek anlamına gelmektedir. -(U)r ekini alarak, düşünen, kendine özgü fikirleri olan kimse ve cümle içerisinde İslam'ın önde gelen âlimleri veya fikir adamları ifade etmektedir.

\section{-(I)ş, -(U)ş:}

İsim-fiil eklerinden biridir. Fiilin gösterdiği işin sonucu veya ürünü olan kelimelere somut ve soyut anlam vermektedir.

\section{1. "Muazzez elbisesinin ve ellerinin yapış yapış olduğunu fark etti.” (KY, s.127)}

$\mathrm{Bu}$ ek, fiile gelerek cümle içerisinde tekrarlama yoluyla kelimeye nemden, terden elbisenin ve ellerin birbirine yapışmış olma anlamı vermektedir.

\section{2."Zekiye kurllganlı̆̆ın hissettiren davranışlarda bulunur.”(VYS, s. 15)}

Davranmak fiili -(I)ş ekini alarak, davranma işini harekete dökme anlamı vermektedir. Cümle içerisinde davranış kelimesi, dışarıdan gözlemlenebilecek tepki anlamına gelmektedir.

3. "Dönüş yolculuğunun en sonunda Liverpol Limanindan Dersaadet'e gidecek gemiye bindiklerinde...”(AN, s.18)

Dönüş kelimesi, -(I)ş eki ile birlikte dönme işi anlamına gelmektedir. Cümle içerisinde varılan bir yerden tekrar eski yerleşim yerine dönme olarak kullanılmaktadır.

\section{4. "Senin yaradıhş̧nda bir valide ister ki benim gibi evlat yetiştirsin.” (VYS, s. 20)}

Yaratmak fiili, İslam inancına göre Allah'ın yoktan var etmesi, kelime anlamına göre olmayan bir şeyi var etmek anlamına gelirken, -(I)ş eki ile birlikte cümle içerisinde var olan bir şeyin doğuştan kazanmış olduğu özellik, mizaç, huy anlamlarına gelmektedir.

5. “...hiçbir kitaba girmemiş, belki de hiçbir zaman girmeyecek olaylar, olgular, savlar, antisavlar, buluş ve icatlar...” (BİS, s.31)

Buluş kelimesi, -(U)ş ekinin eklenmesiyle, yeni bir şey ortaya koymak, üretmek anlamı kazanmıştır.

6. “Demek görüş alanina girmiştik artık.” (BİS, s.48)

Görüş kelimesi görme işi anlamından ziyade cümle içerisinde ilgi alanı, dikkati çekmek anlamında kullanılmıştır.

7. “...hevesçe kurgın görünen toplumlar, yeni bir doğuş ve diriliş firsatını kaçırabilirler.” (FÖ, s. 10)

Doğuş ve diriliş kelimeleri, aldıkları ekle birlikte cümle içerisinde, tekrar canlanma, hızlı bir ilerleme, yeni bir güç kazanma anlamını ifade etmektedir.

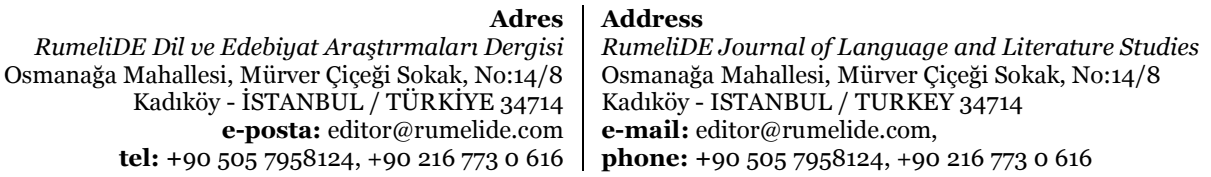

Adres
RumeliDE Dil ve Edebiyat Araşttrmaları Dergisi , Mürver Çiçeği Sokak, No:14/8 -posta: editor@rumelide.com tel: +90 $5057958124,+902167730616$
Address

Osmană

e-mail: editor@rumelide.com

phone: +90 5057958124, +90 2167730616 


\section{$-(I) t,-(U) t:$ \\ -(I)t, -(U)t:}

Eski Türkçeden beri kullanılan bir ek olup örnekleri fazla değildir. Fiilden somut ve soyut isimler yapar. Adların birkaçı yer adı, birkaçı fiilin gösterdiği işin ürünü olan nesne ve yiyecek adları, birkaçı da vasıta görevine dayalı araç-gereç adlarıdır (Vural ve Böler, 2012, s.177).

1. "Sonuncu top hep kapinın dişındadır ve Malraux'nun tüm yapttar bu acı gerçekle dokunmuştur.”(BİS, s. 48)

$\mathrm{Bu}$ ek, fiile, fiilin işaret ettiği hareketin sonucu olan ürün anlamında kelime türetmiştir. Yapıt kelimesi, bir emek sonucunda ortaya koyulan ürün anlamına gelmektedir.

-Av:

Ek, bir hareketin sonucu, ürünü anlamında isimler türetmiştir.

1.“Ancak bütünle birlikte bir yarar ve işlevleri olabilir.” (FÖ, s. 66)

Bu ek, işlemek fiiline, fiilin bildirdiği hareketin sonucu anlamı katmaktadır. İşlek olma, kullanılabilir olma, iş görme yetisine sahip anlamını bildirmektedir.

-sAk> -sA-k>-Ig+sA-k:

Fiilin gösterdiği işi üzerinde nitelik olarak taşıyan veya o işe meyilli, istekli olan anlamında ad ve sifatlar türetmiştir.

1.“...adaletsizliğin, tembelliğin tutsă̆̊ gibi kendi kendine kavrulup duruyor.”(FÖ, s.12)

-sAk eki, tut fiilinin gösterdiği anlamı üzerinde bulundurulan kimse vermektedir. Tutsak kelimesi, esir edilmiş, içinde bulunduğu durumdan kurtulamayan anlamını ifade etmektedir.

\section{-mAksIzIn:}

-mAk ad-fiil, -sIz yokluk ve -In vasıta durumu eklerinin kaynaşmasından oluşmuş birleşik bir ek türüdür(Korkmaz, 2009, s.96).

1.“Bu olmaksızın mücerret dilek ve temenni, bir çelişkiden başka bir şey olmaz.” (FÖ, s.45)

Eklendiği fiile -mAdAn anlamı vermektedir. Bir şeyin meydana gelmesi veya bir kimsenin bir şey yapabilmesi için eklendiği fiili şart olarak göstermektedir.

\section{-(y)ArAk:}

-(y)A zarf-fiil ekinin -rAk karşılaştırma ekiyle genişletilmesinden oluşmuş çok işlek bir ektir (Korkmaz, 2009, s. 74-75). Kök anlamını değiştirmez ancak pekiştirir.

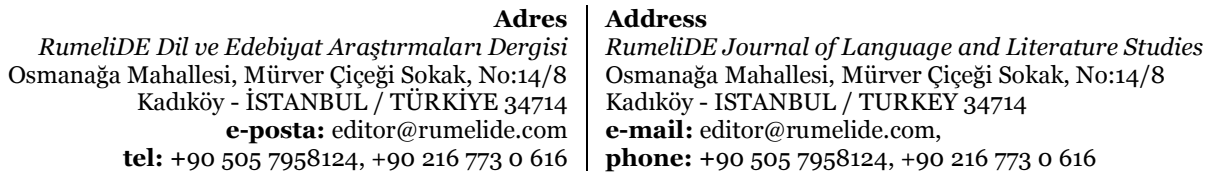

tel: +90 505 7958124, +90 2167730616

phone: +90 $5057958124,+90216773$ o 616 
1. “Bunun dışında iddiaları olanlar, bilerek bilmeyerek bir yozlaşmaya kapı aralamakta...” (FÖ, s.27)

-ArAk eki, fiilin olumlu ve olumsuz hallerinde tekrarlanarak, farkına varmadan veya farkında olarak ihtimalli bir anlamı ifade etmektedir.

\section{2. “Giderek teori ile pratiğin arası açıldı.” (FÖ, s.72)}

Burada da, git fiiline, artarak, zamanla anlamı vermektedir.

\section{-AnAk:}

Eskiden beri devam edip gelme, yer bildirme, bir niteliği üzerinde bulundurma” gibi anlamlarda somut ve soyut isimler meydana getirmektedir.

“...nerdeyse gelenek haline gelmiş alemimizde.” (FÖ, s.21)

Bu ek, gelmek fiiline, eskiden beri devam edip gelme, atalardan kalma anlamı vermektedir.

\section{Sonuc}

İsim yapmak için biçimbilgisiyle de ilişkili en yaygın yöntem türetimdir. Türetim, yapım eki şeklindeki soneklerle yapılmaktadır. Bunlardan biri de fiilden isim yapan eklerdir.

Fiilden isim yapan ekler, fiil kök veya gövdelerine gelerek isim türetirler. Bu türetme, morfoloji veya biçimbilgisi adı altında incelemektedir. Eklerin, eklendikleri kelimelere kazandırdıkları anlam ise, morfo-semantik olarak tanımlanır.

Türkiye Türkçesinde fiilden isim türeten eklerin morfo-semantik işleyişleri şu şekilde tespit edildi:

1. Eklerin işleyişleri ile anlamları arasında bir ilişki vardır.

2. Ancak eklerin anlam değiștirme gücü farklı farklıdır. Bazen çok yakın bir anlam verilirken, bazen kökle gövde arasında bir anlam uçurumu oluşur. "güvenme" kelimesindeki -mA eki kök anlamı ile ilişkili anlam kazandırırken, "ezme" kelimesi bir yemek adı anlamını kazanmıștır.

3. Anlam değişmeleri eklerin, derin ilişkileri olduğu görülmektedir.

4. Ekler kelimenin türünü değiştirmeden fiilden o fiille ilgili yeni bir isim türetmesi, dilin yeni kelime ihtiyacına hizmet etmektedir. Korkan kişi demek yerine korkak kelimesinin kullanılması gibi.

5. Fiilden yeni isim türeten bu ekler, kelimelerin yan anlam kazanmasına da katkıda bulunur. Örneğin, keskin kelimesinin aletler için kullanılabileceği gibi ses ve bakış için de kullanılabilir.

6. Kimi sözcüklerde ise tek başına anlam ifade etmeyen kelimelere gelerek anlamlı bir kelime oluşturmuşlardır.

7. Ekler, bazı örneklerde eklendikleri kimi sözcüklerde kök anlamı ile ilgili bağlantılı (bakımlı kelimesi) olmalarına rağmen, cümle içerisinde farklı anlam kazanan kimi sözcükler (konuk kelimesi), kök anlamının dışında yeni bir anlam kazandırmışlardır.

8. Morfo-semantik türetme ile yeni bir anlam kazanan sözcükler, sözlüklerde madde başı olmuşlardır. Bilgiç, görücü, dönüm, başlangıç vb.

\begin{tabular}{|c|c|}
\hline & \\
\hline $\operatorname{larn} D$ & Studie \\
\hline , No: & manağa Mahallesi, Mürver Çiçeği Sokak, No:14/8 \\
\hline $\begin{array}{r}\text { Kadıköy - ISTANBUL / TÜRKİY } 34714 \\
\text { e-posta: editor@rumelide.com } \\
\text { tel: +90 505 7958124, +90 } 2167730616\end{array}$ & $\begin{array}{l}\text { Kadıköy - ISTANBUL / TURKEY } 34714 \\
\text { e-mail: editor@ rumelide.com, } \\
\text { phone: +90 505 7958124, +90 } 216773 \text { o } 616\end{array}$ \\
\hline
\end{tabular}


9. Bazen eklerle anlam değiştirme yerine ek almadan da anlamın farklılaşması durumuyla karşılaşlır. Bu incelenmesi gereken bir durumdur.

10. Türkçe eklemeli bir dil olmasının yanında başka dillerin etkisiyle farklı anlam yükleme sistemlerine sahiptir.

11. Eklerin eski zamanlarda kelime olma ihtimalinden dolayı, birleşik yapıya benzediği için, anlamı değiştirme özelliği düşünülebilir. -AcAk, AğAn ekleri gibi.

\section{Kisaltmalar}

VYS: Vatan Yahut Silistre

KY: Kuyucaklı Yusuf

BİS: Balık İzlerinin Sesi

SER: Sergüzeşt

AN: Aşkname

FÖ: Fizikötesi Açısından Ufuklar ve Daha Ötesi III- Doğum Işı̆̆ı

TTF: Taaşşuk-1 Talat ve Fitnat

GK: Geçmişin Kuşları

\section{Kaynakça}

Akbal, O. (2004). Geçmişin Kuşları. İstanbul: Alkım.

Ali, S. Kuyucaklı Yusuf. İstanbul: Yapı Kredi.

Banguoğlu, T. (2011). Türkçenin Grameri. Ankara: TDK.

Ergin, M. (2004). Türk Dil Bilgisi. İstanbul: Bayram.

Karaca, H. (2013). Türkiye Türkçesinde Eklerin İşlevleri. Cumhuriyet Üniversitesi. Sosyal Bilimler Enstitüsü. Basılmamış Doktora Tezi.

Karaoğlu, S. (2018). “Türetimlikler”. Ed: Erdoğan Boz. Türkiye Türkçesi II-Biçimbilgisi. Ankara: Gazi.

Karakoç, S. Fizikötesi Açısından Ufuklar ve Daha Ötesi III- Doğum Işığı. Diriliş: 4.Baskı

Kemal, N. (2013). Vatan Yahut Silistre. Antik Dünya Klasikleri.

Korkmaz, Z. (2009). Türkiye Türkçesi Grameri- Şekil Bilgisi. Ankara: TDK

Pala, İ. (2012). Aşkname. İstanbul: Kapı

Sami, S. (2020). Taaşuk-ı Talat ve Fitnat. İstanbul: Arpa.

Sebzecioğlu, T. (2017). Dilbilim Kavramlarıyla Türkçe Dilbilgisi. İstanbul: Kesit.

Sezai, S P. (2005). Sergüzeşt. İstanbul: Beyaz Balina

Uzuner, B. Balk İzlerinin Sesi. İstanbul:Remzi, 4. Basım.

Vural, H; Böler, T. (2012). Ses ve Şekil Bilgisi. İstanbul: Kesit 